This item was submitted to Loughborough's Research Repository by the author.

Items in Figshare are protected by copyright, with all rights reserved, unless otherwise indicated.

\title{
Making sense of stakeholder values emergence
}

PLEASE CITE THE PUBLISHED VERSION

http://dx.doi.org/10.1080/21573727.2014.940895

\section{PUBLISHER}

(c) Taylor \& Francis

\section{VERSION}

AM (Accepted Manuscript)

\section{PUBLISHER STATEMENT}

This work is made available according to the conditions of the Creative Commons Attribution-NonCommercialNoDerivatives 4.0 International (CC BY-NC-ND 4.0) licence. Full details of this licence are available at: https://creativecommons.org/licenses/by-nc-nd/4.0/

\section{LICENCE}

CC BY-NC-ND 4.0

\section{REPOSITORY RECORD}

Mills, Grant R., and Simon A. Austin. 2019. "Making Sense of Stakeholder Values Emergence". figshare. https://hdl.handle.net/2134/22736. 


\section{Making sense of stakeholder values emergence}

MILLS, G.R.W. ${ }^{1 .}$ and AUSTIN, S.A ${ }^{2 .}$

1. Bartlett School of Construction and Project Management, University College London, WC1E 7HB

2. School of Civil and Building Engineering, Loughborough University, Loughborough, LE11 3TU

\section{Contact Address:}

The Bartlett School of Construction and Project Management,

University College London,

Room 239, 1-19 Torrington Place,

London,

WC1E 7HB.

Email: g.mills@ucl.ac.uk 


\title{
Making sense of stakeholder values emergence
}

\author{
MILLS, G.R.W. ${ }^{1 .}$ and AUSTIN, S.A ${ }^{2 .}$ \\ 1. Bartlett School of Construction and Project Management, University College London, WC1E 7HB \\ 2. School of Civil and Building Engineering, Loughborough University, Loughborough, LE11 $3 T U$
}

\begin{abstract}
Relatively little is known about how the concept of sensemaking is triggered by knowledge of human values during the multi-stakeholder decision-making process of construction projects. The emergent, complex and dynamic nature of a cultural value and values system is modelled on a longitudinal case study to demonstrate stakeholders' unique perceptions. Empirical data was gathered through action research and using value in design (VALiD) to structure stakeholder dialogues at three interventions in the briefing and design stages of a new primary school project over a two year period. Schwartz's (1992) theory of human values was subsequently used to theoretically triangulate and postulate on the emergence of unique stakeholder values. The findings contribute new insights into the complex and emerging inter-relationship between stakeholder value and values systems. It provides a dynamic perspective of a project culture and illustrates the role of universal values in supporting sensemaking.
\end{abstract}

Keywords: Emergence, Project, Sensemaking, Stakeholders, Values, Value 


\section{Introduction}

Although the construction industry can manage technical and process complexity proficiently, it needs better ways to deal with, and routinely manage, the social and cultural complexity of its activities in order to establish meaningful and values-laden relationships between stakeholders.

Every individual or group will have values that are partly unique and partly shared, and universal values are those that are shared by all people, across all nations, ages, backgrounds and religions and hence existing and persisting in an 'objective sense’ (Haller, 2002). This article seeks to understand unique stakeholder values and to understand how unique values are triggered and emerge from the dynamic interaction of stakeholders across the social life of a project.

The intertwined relationship between stakeholders' unique values and the emergence of a shared project culture is investigated. Previous work has sought to understand values in a universal sense (Mills et al., 2009). In contrast, this article addresses the need to understand the unique and emergent values of diverse stakeholders during the management of projects. It describes how a dynamic culture emerged on a longitudinal case study through three phases of design, as a means of characterising the dynamic shaping and reshaping of a projects value and values system and challenges the establishment of a shared culture.

Fellows and Liu (2013, p. 4) state that projects are unlikely to establish a culture per se, but rather a dynamic environment and 'project atmosphere' that modifies behaviour at a lower level. Culture, on the other hand, is abstract, long-term and socially determined; it is often associated with psychological traits and beliefs, rather than with emergent, dynamic and incentive-driven interactions. Throughout this article the term culture is used to mean the shared beliefs, values, and assumptions that guide sensemaking and action in organizations (Ott 1989) and which is achieved through socialization (Van Maanen, 1976).

A dynamic view of culture now prevails; for example Kotter and Heskett, 1992 and Attwood et al., 2003 have built off Mintzberg's (1978) view of strategy as 'pattern[s] in a stream of decisions' and Swindler's (1986) conception of culture in action as a toolkit of symbols and strategies. Although construction management research seems stuck in a somewhat outdated paradigm that applies static models of culture. This article responds to calls made by Bresnen et al. (2005) to understand the 'taken-forgranted values, assumptions and meanings' that are critical in 'recogniz[ing] that there are multiple stakeholders within any given society and that alternative values, perspectives, visions, and stories co-exist and compete with those promulgated by the 
dominant group or groups’ (Brady et al. 2005, cited by Bresnen et al., 2005, p.490).

Few authors have analysed the longitudinal content of a projects multi-stakeholder value and values system as triggered in discourse, trade-offs and subjective judgement over the evolving design process, as is done here. This research investigates the unprompted emergence of unique values when stakeholders debate their assessment of the value of a new building in terms of 'value criteria'. It is hoped that this understanding will help characterise culture, not as a normative trait (of an individual or group) but as an agile and values-rich process activity that is socialised, lead and made sense of by stakeholders, both individually and collectively.

\section{The value and values constructs}

Before exploring the relationship between value and values, it is important to differentiate between the two terms, as they are sometimes misunderstood or conflated. Values are moral principles and beliefs or accepted standards of a person or social group. Schwartz (1992) defines five features: 'beliefs' (cognitive structures that become infused with feelings), ‘desired goals’ (with motivational ends which people strive to attain), 'transcendence of specific actions and situations' (as socially desirable goals which people think they ought to realise), 'ordered relative importance' (forming a system of value priorities that characterise cultures and individuals) and 'standards or criteria' (used to judge most things as either good or bad).

Applied fields define the characteristics of values through concepts such as: learned through socialization (Hofstede, 1998), owned through 'participation’ (Baines, 1998), ‘drive[ing] strategy’ (Sawhney 2002), 'supporting the employee-manager interface' (Brown, 1976), forming a 'moral compass' (Hitlin and Piliavin, 2004) and supporting selforientated alignment around organisations (Wiener, 1988).

Rescher (1969) suggests that values should be expressed as positive statements, 'otherwise we would speak of disvalues', while others link values to behaviour and the importance of them being lived as well as expressed (Jaffe, 1998; Jones and Pollitt, 1999; Desjardins, 2002; Sawhney, 2002; Smith, 2002; Bardi and Schwartz, 2003; Peat, 2003; Hitlin and Piliavin, 2004; Schwartz, 2005). Many of these same characteristics may also be features of value - a more operationalised term that is less abstract and is closely related to day-to-day strategies, behaviours and qualities, as will be shown. Broadly speaking values are social and psychological, while value is a sociotechno phenomenon.

With regards to value, it may be treated as either a noun or a verb and is the desirability or meaning of a thing, a monetary valuation, an exchange, or a quantifiable amount. As a verb, value is an assessment or estimate, with some regard or material worth. 
Values cannot be quantified as monetary worth in the same way, nor based on exchange.

Value is defined within soft value management as a 'subjective term ... manifested in different ways such as attitude, belief, desire, preference, need and criteria’ (Leung and Liu, 2003, p. 11). It is ‘achieved when client satisfaction exceeds the resources invested ... enhanced when the same [and more desired] functions are provided at a lower cost' (Kelly, 2007, pp. 435-436); it 'changes with time' and 'is influenced by the current circumstances' (McGeorge, 1997). For Dallas and Humphrey (2004, p. 11) it involves a 'relationship between the benefits delivered [sought by the commissioner] and the use of resources [what the commissioner is willing to pay]' and so is 'a balance between two conflicting requirements'. It is also 'not absolute, but relative', is 'viewed differently by different parties in differing situations' and 'requires balancing a series of conflicting parameters to arrive at an optimum position’ (British Standards Institute, 2000, pp. 1314). According to Mills (2013), value and values are:

a) Judged in relative terms and differently by various stakeholders and emergent over time.

b) Uniquely understood, multi-attribute and multi-dimensional: owing to their abstract nature, values can be viewed as (somewhat) universal, while value is defined and measured by a complex of concepts. c) Nested, aligned and aggregated at various social levels.

d) Intertwined with behaviours and qualities: values are always implicit in value judgements and evidenced directly in behaviour, while value is evidenced indirectly in qualities (Mills, 2013).

\section{Universal values theory}

According to Schwartz (2005) universal values, approximately speaking, fall into one of ten universal values categories within a quasi-circumplex system. This motivational continuum has 'fuzzy' lines of segregation, where adjacent universal values are congruent because they share an underlying need or motivational goal, while those which are opposite in the circle conflict, because their underlying motivations are opposed. Figure 2 is an adaptation of the model of Schwartz and Boehnke (2004), which pictures the '...total pattern of relations of conflict and compatibility among values priorities’ (p. 231).

[Insert Figure 2 Here]

Schwartz's model of universal values (Figure 1) was selected on the basis that it provides the broadest and most theoretically robust instrument (Mills et al., 2009), the Schwartz Values Survey (SVS). Some 64,000 people have used the SVS, across 67 countries, from highly diverse geographic, cultural, linguistic and religious backgrounds. Schwartz used 
confirmatory factor analysis, with just under 11,000 people over 27 countries, to revalidate his theory. Schwartz's model and fundamental motivational continuum can be regarded as the most advanced universal values theory to date and can help individuals and organisations move beyond studying independent and singular values, to think about values systems and the dynamic interrelated structure of values (Mills et al., 2009). It was therefore selected as the most suitable categorisation of human values for the purpose of the research in hand.

Universal approaches have been applied within construction management to understand the implicit structures of values between supply-chain organisations (Mills et al., 2009) to align individual and organisational values across regional offices (Zhang et al., 2008) and to elicit a unique design brief for various primary schools (Mills, 2013). But, while these applications are theoretically robust, they are limited by a relatively static and structured application of universal values measurement.

\section{Dynamic and non-unitary values}

Outside of construction project management Bourne and Jenkins (2013) demonstrate the need for a dynamic, non-unitary view of values over time that are temporal and changing. They distinguish between four organisational values forms. These included espoused values (values that top managers sanction through written and formal documents), attributed values (generally representative, but not necessarily shared or aspired to), shared values (an aggregate culture that is established through socialization and has an individual-organizational fit), and aspirational values (the values of the organization in the future according to changing trends in social life). The implication of these different values is that for most organizations there are '...shifting overlaps and gaps between the forms of values...' which means that they 'remain in a state of flux' (p. 505). These findings lead to various propositions, which state in part that organizational underperformance will lead to a search for alternative values. If such values are adopted, an expectation gap will emerge between intended forms of values (aspirational and espoused) and those embedded in the organization's past (attributed and shared).

\section{Culture as a guide for sensemaking, sensegiving and emerging individual schema}

Organisational culture is the shared beliefs, values, and assumptions that guide sensemaking and action in organizations (Ott 1989) and which is achieved through socialization (Van Maanen, 1976). According to Harris (1989, p. 178) 'Organizational culture is a concept that bridges the gap between individual- and group-level phenomena' and '...is shared and maintained at the group level of analysis but operates 
primarily by facilitating the individual level act of sensemaking'. Furthermore, Van Maanen and Barley state that 'while a group is necessary to invent and sustain culture, culture can be carried only by individuals’ (1985, p. 35).

Sensemaking is taken as a trade-off interaction that enables individual and organisational adaptation and integration (Weick, 1969). It is how individuals (particularly leaders) make sense; their mental models of the organization and sense of their environment. It is a learning, theory building and decision making process, which is initiated by inadequacy, i.e. a perceived sacrifice, need for improvement, incorrectly held values, or lack of integrity in their translation into action. Greater clarity and understanding of values in all their forms will support sensemkaing.

Others have differentiated sensegiving; the ability to communicate and motivate others to support mental models (Gioia and Chittipeddi 1991). For Bartunek et al. (1999), leaders in sensemaking scan the internal and external environment and '...engage in meaning construction [and latterly reconstruction] as they attempt to develop a framework for a potential strategic change'. While, sensegiving, involves leaders selecting priorities, ‘...defining for others a revised conception of the organization' and so 'attempts to influence others'. A third process is the 'negotiation of interpretations between the leader and other members' (p. 39). Values awareness to align and establish an individual-organizational fit is therefore crucial.

Others have termed this dynamic understanding of culture as a schema-based perspective. It is how individuals use organizational culture to make sense (encode, represent and process information, build mental maps, respond to stimulus and orientate themselves within a ready-made and experiential terrain or system) (Harris, 1989, 1994). In this view it is values and principles that drive culture and harness change. This view is aligned with Attwood et al., (2003) who conceptualise a continually adapting and emerging temporal holding framework (values and principles that articulate and simplify the complexity of a system) as a means to lead cultural change. Understanding of values may therefore support individuals to make sense, however little is known about the emergence of existing individual schemas.

There are according to Harris (1994), five categories of in-organization schemas involved in sensemaking: self-in-organization (individuals' theories and generalizations such as personality, values, roles, and behaviour), person-in-organizations (perceptions and attitudes of others such as organized memories, expectations, roles, traits, and goals), organization (the generalised and aligned cultural type), object/concept-in-organization (physical and verbal artefacts that have meaning and act as stimuli or perceived as having 'value' or 'quality'), and event-in-organization (these are social contexts, 
situations, encounters, interventions, ceremonies, project environments. Open systems thinking rituals and appropriate and expected behaviours). (Sherman, 1998) and Argyris and Schon’s (1978) According to Harris (1994, p. 313) '...event schemas view of double-loop learning incorporated the need can be overlaid on other schema categories to create more specific in-situation schemas’.

for deeper reflection on values, greater creativity and critical thinking.

From a wider market-based view, Normann and Values as a knowledge bridge between individuals

Values could provide a cultural bridge to align individuals and organizations on projects. Various previous and contemporary literatures have described the establishment of a shared sense of meaning. From a knowledge-based perspective Grant (1996) states that common knowledge (e.g. universal human values) is critical in forming the '...intersection of their individual knowledge sets’ (p. 115). In addition, culture permits individuals to invade one another's functional boundaries and provides a common basis for integration. In sensemaking, this combined knowledge allows specialists to cross one another's functional boundaries to maximise value (Hasan, 1999; Hasan and Gould, 2001).

Weick developed the notion of 'loose coupling' (the degree of flex between an organization's internal abstract frames and the outside world). In addition, 'communities of practice' have been investigated between loosely coupled professional networks, which transcend the boundaries of organizations (Brown and Duguid, 1991, 2001) as is also the case in

\section{The project value environment}

Empirical evidence to describe the dynamic nature of a project culture as created by multi-stakeholder temporal frames is somewhat elusive. Some, such as Emmitt et al. (2005) and Thomson, et al., (2011) have noted the complexity. Authors in the fields of project 
and value management have espoused the importance of establishing a value culture (British Standards Institute, 2000) or the importance of values elicited in workshops (Kelly, 2007). Thomson et al. (2013) has investigated the collective mental model of value for the construction industry using free-listing techniques from cultural anthropology. While others have focused on singular values concepts such as ‘creativity' (Kirk and Spreckelmeyer, 1988) and ‘collaboration’ (Thiry, 2001). Few have combined these perspectives or tried to empirically investigate the relationship between value and values system emergence.

In order to understand values within the context of construction projects, Figure 1 visualises three perspectives, where a past view: a) is the transactional asset exchange view presented by Kelly et al. (2004) between the project and the core client's primary business activity; b) is an expanded view of projects as a temporary network of loosely coupled firms that disband after project completion (Akintoye et al., 2003; Dubois and Gadde, 2002). Some concepts such as design chains, integrated teams and systems integration are useful functional descriptions, but do not provide a cultural standpoint on integration (Austin et al., 2001; Strategic Forum for Construction, 2002; Davies et al., 2006, 2009).

The most contemporary view is c) a stronger values-rich and mutual-benefit relationship view that acknowledges the interdependence between customer, provider and wider stakeholder systems (Freeman, 1984; Hillman and Keim, 2001; Bishop et al., 2003; Freeman et al., 2004) value co-creation (Vargo et al., 2008; Grönroos and Vaima, 2012; Helkkula et al., 2012). This perspective provides a service- and resource-driven structure for value; set within a broader system and market view of construction projects. Where value is determined in business use and accumulates over time, rather than through a one off exchange.

While contemporary views provide an important conceptualization; construction management research has explored many practical value opportunities. For example supply chain management (Green et al., 2005; Fernie and Thorpe, 2007), knowledge management (Tennant and Fernie, 2013), organizational learning (Barlow and Jashapara, 1998; Henderson et al., 2013), front-end and service-led approaches (Johnstone et al., 2009; Morrey et al., 2013; Morris and Hiugh, 1988; Edkins, et al., 2013; Morris, 2013), uncertainty (Perminova et al., 2008) and the establishment of customer relationships (Pryke and Smyth 2006; Skitmore and Smyth, 2007; Fellows and Liu, 2013). Still others have discussed the commitment, chemistry and emotional attachment that result from project participation (Nicolini, 2002; Dainty et al., 2005). Figure 1c is used later to discuss the nature of the empirical findings presented in this article (Table 1) to describe the project ontology and 
environment for value and values sensemaking and socialisation.

[Insert Figure 1 Here]

\section{Values elicitation practices}

The design field has perhaps been more comfortable to apply creativity in addressing complex cultural socio-technical phenomena. For example cultural probes are an inductive design method used to elicit and respond to subjective thoughts, values, uncertainties and cultural artefacts (Gaver et al., 1999, 2004). Within the construction field, authors such as Luck et al. (2001, p. 307) have called for the 'inclusion of the human dimension [and] dialogue to provoke ideas and resolve conflicting needs', although design qualities rather than social determinants such as values have often resulted. Luck (2012) proposes ethnomethodology and conversation analysis as the primary means of studying the natural conversations and interactions that structure design practice and to illustrate designers' 'ethnomethods’ as a social theory of action. However, others have demonstrated that there is a natural cultural bias and that designers may implicitly apply their own values (Lera, 1981). A wider and multi-stakeholder orientation (beyond the designer alone) is therefore required to appreciate and align the values of clients, users and other stakeholders.
Another elicitation approach that forms part of the artificial intelligence toolkit is means-ends analysis (Newell et al., 1959; Newell and Simon, 1972) and laddering, which is '.... method of probing during indepth, one-to-one interviews...'. Laddering was designed to understand the salient and deeper bases of decisions and consequences of choice. By asking 'why' questions, a means-end chain (a simple mental model) is elicited that links product attributes and functional benefits to a personal values item such as achievement (Christensen and Olson, 2002, p. 480).

\section{Research method}

This study is focused on 'values' as a conceptual unit of analysis, as triggered through the definition and assessment of value during design. This work explored greater mobilisation of emergent and embedded concepts, beyond those identified from past research (e.g. value and values).

The study benefitted from a single and unchanging set of project-specific stakeholders. Whilst this was ideal for the action research, most live projects are not so convenient and may experience significant participant churn.

\section{Background to the longitudinal case study}

The study refers to a £7.4 million primary school and Sure Start centre in Manchester. The brief required a 420-place primary school (the existing one was 350), a 60-place nursery and a 60-place 0-3 Sure Start 
Centre with a 12-place crèche. It involved a broad range of stakeholders: local councillor, regeneration, planning, sustainability, teacher leadership, teachers, building management, client, project management and construction supply) in design evaluation. There were thirty project interventions with these eleven stakeholders (11 to define value in briefing, 9 to assess value in conceptual design and 10 to assess value in detailed design). This live application ran alongside a tried and tested project management delivery process (based on PRINCE II), involving observation of regular progress and core design team meetings which addressed specific design issues such as building governance, space, equipment, lighting and site layout.

Manchester City Council and their 'Framework One' team had built up extensive expertise that was consolidated into a primary education strategic briefing document, informally known as the 'Red Book’. As named after Manchester United Football club. This strategic briefing document outlined the need to both deliver against generic national and local standards and local community needs and aspirations. This quality assurance document was reviewed and updated on a project by project basis and was version managed to ensure that all members had the most upto-date copy. This document was well regarded by internal delivery teams, however the specification were sometimes seen as undeliverable externally by the supply chain against the budget and contract cost.

\section{Research design}

The real-time action research (Greenwood et al., 2007; Waterman et al., 2001) approach applied in this study enabled the development of a more sophisticated understanding of value and values, and provided longitudinal case study evidence of the relationship between these two concepts. A case study protocol and rigorous database / data store were used to help ensure reliability, as recommended by Yin (1994). Previous research informed the planned units of analysis, although emergent and embedded units of analysis resulted from action, observation and reflection. The latter are described elsewhere (Mills, 2013).

The principle focus of the action research was the support of a novel stakeholder consultation process that ran alongside the existing briefing and design review process. The new process involved multiple stakeholders in the definition and assessment of design against multiple value criteria.

The case study research design used a mixed abductive grounded theory approach, including action research, survey, interviews, observations and various data analysis methods, in which an author was directly embedded and situated in organisational and project environments. Action research was applied with little separation between analysis and action to make a direct and immediate impact on the project situation. This allowed the researcher to recount the real-time, real-world situation observed, clarify ideas and 
research questions, shape and re-shape development and understand and discover, as in Orton (1997). This captured reality more effectively; however, it also introduced bias and limited the deductive and inductive clarity

The research was driven by the core project team, who determined the level of information provided to each stakeholder. A structure to guide emerging stakeholder involvement was created (Mills, 2013) to define interventions and drive consultation based on Arnstein (1969). It also created a stakeholder-unique process addressing individual stakeholder priorities in a timely fashion as design fixity decisions were made.

\section{Value in Design (VALID)}

A categorical and thematic framework (Figure 3), previously presented by Thomson et al. (2003) was in part applied. Its three parts enable stakeholder participants to:

a) understand each other's values so that compromises can be made when reaching a single solution;

b) inform project design by setting baseline target expectations for value delivery against selected generic (or customised) outcome criteria; and

c) judge value delivery in terms of the multistakeholder trade-offs between benefits, sacrifices and resources throughout the project life cycle and between alternatives, from inception through to obsolescence.

This article applies steps 2 and 3 as a means of understanding step 1 and as such challenges the sequential logic of 1-2-3. Our previous research treated the value and values concepts separately and sequentially. We stated that one may be explored without the other, but that ideally the two should be addressed simultaneously (understand values and then define and assess value). In application, however, it was evident that there was a more complex and fuzzy relationship in which value and values were intertwined, with one triggering expression of the other.

\section{[Insert Figure 3 Here]}

\section{Establishing value criteria}

A literature review led to the customisation of a set of outcome criteria based on published work (Thomson et al., 2003; Austin et al., 2008). This elaboration to form education-specific set of criteria was informed by policy and building guidance from Building Schools for the Future, CABE, Design Council, DfES and RIBA between 2002-5 (Mills, 2013). A concise set of 55 school-specific outcome criteria was then identified for simplicity and efficiency. These criteria were grouped under eleven familiar categories and aligned with the Design Quality Indicator (DQI). All stakeholders used this set of generic building criteria in steps 2 and 3 as a starting point to capture 
quantitative and qualitative assessments, although new criteria were defined when requirements emerged.

\section{Value definition and assessment}

Stakeholder representatives selected outcome criteria by a card sorting method, choosing a small subset of generic criteria (twenty-five or fewer) to monitor the delivery of value, as seen from their perspective. After entering all stakeholders' selected criteria into an excel-based value dashboard, a single researcher guided stakeholder representatives through the definition of targets relative to their experience, on a standard ten-point semantic scale to enable the making of judgements,

\section{Unique values elicitation}

Assessments were made in face-to-face interviews and multi-representative workshops, depending on the nature of each stakeholder group. This provided the opportunity to capture rich qualitative data that could be compared with quantitative data. In these thirty interventions one of the researchers met with each participant, all but one face-to-face, and used laddering and means-ends analysis to elicit further stakeholder and situation-specific details when defining value and making judgements in design. During the 'define' stage card sorting helped tease out priorities and target setting prompted a dialogue on the baseline and future expectation for judgement. It should be noted that no direct method for understanding values was applied; rather this phenomena emerged naturally and became the subject of a later, separate analysis that forms the core data of this paper. Across all criteria and all stakeholders, $59 \%$ of stakeholder-criteria were provided with a qualitative comment, returning 109 comments during the definition of 180 value criteria and the subsequent assessment of 132 criteria (including duplicate criteria selected and assessed by more than one stakeholder). The length of these comments ranged from 150 words to just a few.

\section{Results}

\section{Value frames were temporal and emerging}

Empirical data revealed that each stakeholder started the project with a unique definition of value. Each stakeholder selected a unique set of criteria and also prioritised these differently according to their experience baselines and target expectations; thus stakeholder knowledge of the process and product emerged independently. A total of 180 criteria were selected across the eleven stakeholders (accounting for duplication in selection) and no single criterion was selected by all stakeholders. In fact, a relatively small number of criteria (9/52) were defined and assessed by more than $40 \%$ of stakeholders. In addition, 14 criteria were not selected and 6 were selected, but not assessed. Overall there was little difference between customers’ and suppliers’ criteria 
choices, although customers focused more on operational issues (e.g. furniture, accessibility and safety) and construction providers on delivery issues (e.g. knowledge, cleaning, maintenance and finishes). A mix of experiences, expectations, requirements and unique values emerged between stakeholders and as such it is unlikely that these were shared in a cultural sense.

A stakeholder value bar chart shows the level of stakeholder satisfaction at two project stages. Stakeholders' temporal satisfaction was generally below their target expectations in the initial concept design stage (' 1 '), but as the project progressed to detailed design ('2') the satisfaction of some stakeholders increased. Figure 4 shows an example of one category (Functionality) for the eleven stakeholders. It illustrates a multi-stakeholder assessment in the concept and detailed design stage (measured against both baseline experience and expected targets). This provides two temporal snapshots of the project, showing that stakeholders' expectations and judgements of satisfaction shifted over time. Some stakeholders expected more than others. This view created a dynamic picture of multistakeholder perceptions emerging over time in response to the evolving design information.

\section{[Insert Figure 4 Here]}

Stakeholders perceived both negative outcomes (sacrifices - a negative move away from their initial baseline expectations) and positive outcomes (benefits
- a positive move away from their baseline expectations) although most were in the latter direction. The results also reveal instances in which judgements of value differed significantly between stakeholders. There were twelve occasions where one stakeholder perceived a benefit, while another perceived that same criterion as a sacrifice. For example criterion 12, 'Achieves green travel plan', was scored on a range from -4 (the school's head teacher) to 1 (planning representative and the LEA client) during concept design. Negative scores often coincided with a lack of perceived involvement in the process or a lack of knowledge to make an informed judgement.

\section{[Insert Figure 5 Here]}

Figure 5 provides an alternative representation showing the variability in stakeholder baselines (the grey band). The head teacher, regeneration representative and school operators (who were all new to construction projects) showed the greatest variability in relation to their judgements, particularly in the perceived difference between past experience and where they wanted to be (their expectation). Least variability was seen among programme stakeholders, such as the LEA client, constructor partners and the client delivery team, who had greater experience and more realistic expectations. Some instances showed that stakeholders' expectations and judgements changed and shifted over time. Some stakeholders 
expected more than others, creating a dynamic picture of multi-stakeholder perceptions.

\section{Stakeholders expressed unique values}

Table 1 shows the unique stakeholder values that were triggered during the definition and assessment of a subset of 24 value criteria (which are shown in tables 2 and 3). Table 1 also shows the post project associations made in analysis between triggered unique values and the Schwartz Values Survey (SVS) universal values (Schwartz 1887, 1992), modified to a minor extent for the construction industry (Mills et al., 2009).

Table 1 shows the significant variance in the extent to which public ( $n=3$; e.g. a, b and c), customer ( $n=4$; e.g. e, f, $\mathrm{g}$ and $\mathrm{h})$ and provider $(n=4$; e.g. I, j, k and l) stakeholders indirectly (and unintentionally) triggered expressions of their unique values when discussing outcome criteria. In most instances unique values were ascribed to the experience of the building in operation, the existing building and relationships in the project team. What follows is a description of the temporal and valuesrich nature of the value-related dialogue.

\section{[Insert Table 1 Here]}

Table 2 and 3 present the same data as Table 1, but incorporates the stage of the project that the unique values emerged during the longitudinal study. It shows 24 value criteria selected as values were expressed in the discourse of one stakeholder or another. Table 3 is ordered by the Schwartz (1992) Universal values types (see also Figure 1). The exploration of universal values and alignment of unique values is a starting point. We observe that the intuitive association of unique and universal values is sometimes difficult because the language of some stakeholders does not neatly associate, for example 'integration', ‘funky’, compromised'. In these cases, unique values can only be indirectly associated with universal values (with less confidence), and when this is the case it is marked with an astrix. This demonstrated that unique values were triggered from a complex mix of sensemaking schemas (e.g. personal as well as events and objectives) as in Bourne and Jenkins (2013).

The emergence of values on projects was examined in terms of which value criteria and process stages were most values-rich; the purpose was to gain insight into culture as a trait (of individuals or groups), or as a dynamic process activity (e.g. socialization, leadership and sensemaking). Table 2 shows the 24 value criteria ordered according to the number of comments across stakeholders. The table shows that different values concepts were triggered during the design briefing stage, named 'define’ ('0’), during an early design stage 'concept' (' 1 ') and a preconstruction stage 'detail' ('2'). 


\section{Early values salience during design}

Four value criteria (Table 2) were most discussed in terms of unique values. These are: 'Enables safe and stimulating outside learning (criterion 20, which elicited 16 unique values across five stakeholder participants); 'Integrates community public services' (criterion 41, which elicited 14 unique values across five stakeholder participants); 'Achieves green travel plan’ (criterion 12, which elicited 12 unique values across seven stakeholder participants) and 'Meets space requirements of users' (criterion 1, which elicited 12 unique values across three stakeholder participants). Other criteria triggered 10 or less unique values and often involved less than five stakeholder participants. The table details where criteria have been selected and comments have been made without triggering any unique values [C]. It also shows when no comment was provided by a stakeholder participant [N/C] and when a criterion was unselected and unjudged to be relevant ' $X$ '. This reveals that some value criteria may be more general or neutral in terms of how they were perceived and judged by stakeholder participants in terms of values, and so may trigger a greater number of values. It may also show that when more stakeholder participants are involved greater values-diversity may result on projects, a fact hypothesised but not empirically proven elsewhere. Various unique values emerged in a dynamic sense.

[Insert Table 2 Here]
We can speculate that the value criteria that trigger a greater number of unique values may be closer to them in the means-ends chain, or that probing in the definition stages of design briefing (where the questions where around experience, unacceptable and optimal performance and target expectations, as opposed to judgements during design) more readily resurfaced unique values. In addition some stakeholder participants such as 'g', 'I', 'j', 'k' and 'l' varied in their group size (between 2 and 5 people), may have impacted on unique values triggering (either positively or negatively depending on the workshop climate and facilitators approach). Nevertheless, these tables show unique values being triggered throughout three different design stages, although most (78\%) in the define stage. Four criteria $(20,41,12$, and 1) triggered most unique values in the define stage (88\%, $79 \%$, 58\% and 67\%). This may suggest that unique values are easier to trigger in the early stages of projects, where little design information exists; many of the discussions were abstract and related to service provision, as opposed to the physical qualities of a design solution. In design assessment stages stakeholder participants were asked to make assessments of design information, naturally focusing them on the physical entities, rather than social and relational interactions.

Table 2 shows that the stakeholder participants most involved in the operations of the school (' $\mathrm{f}$ ' and 'e'), and to a lesser extent those responsible for the 
schools design and construction ('h', 'j’ and 'k'), most frequently expressed unique values (ascribing them to systems, processes and building elements). We observe that these stakeholder participants had the greatest day-to-day involvement in the project and probably had the greatest professional interest in the outcome. Fewer unique values were expressed by more remote participants in the public councillor, regeneration and planning roles, in site management, the local authority education team, and the local authority sustainability advisory group, which may traditionally be technical subjects (or at least stakeholder participants’ contribution was perceived that way). This may show that these stakeholders are less able, interested or responsible for values-rich design, because values are not triggered during their definition and assessment of value. Greater research would be needed to support this hypothesis and to understand if unique values triggering is more accredited to a trait, role or activity. It cannot be coincidental that stakeholders 'e' (62\%) and ' $f$ ' (71\%) more frequently associate values with the criteria they have selected. When compared against much lower scores from 'a' (7\%) and 'b’ (23\%).

The results for group ' $\mathrm{i}$ ' is surprising, as they triggered 8 unique values. This is low given the group are highly involved in the school design and construction programme, although arguably more concerned with process control and compliance with local and national standards and often referred to the head teachers judgement.

\section{Values support sensemaking under uncertainty}

There seems to be less uncertainty in the briefing (define) stage than in the assessment (concept and detailed design stages), due perhaps to the nature of the process, to peoples' relationship with that process (e.g. they cannot yet identify with it or they feel less able or less responsible to make a value judgement). There are few obvious patterns in the relationship between values and uncertainty (e.g. when a stakeholder participant states that they require more information to make a value judgement). Uncertainty on a criterion is often repeated for a single stakeholder and over project design stages. For example use criterion '9 - Enhances teaching and learning' was uncertain for stakeholder ' $h$ ' 3 times across stages 0,1 and 2; this stakeholder was repeatedly faced with uncertainty. This suggests that an improvement in information flow could drive better reflective decision making (Bucciarelli, 2002), sensemaking (Weick, et al. 2005), sensegiving (Gioia and Chittipeddi, 1991) and stakeholder satisfaction (Kärnä, et al., 2013) with their experience of the design process.

Uncertainty on a criterion can also exist between stakeholders, for example three stakeholder participants ('e', 'h' and 'I') have required information on criterion ' 12 - Achieves green travel plan’ across two stages. Interestingly, four criteria (9, 
12, 20, 44), most frequently judged by stakeholder participants to be uncertain, also triggered a high number of unique values (9, 12 and 16 unique values respectively). While, others did not; criteria 4, 22 and 44 triggered 2, 3 and 1 unique values respectively). This is inconclusive as to whether values are expressed when uncertainty exists; instead the triggering of unique values may be more related to the value criterion itself, stage in the process (e.g. level and fixity of product qualities-based design information) or the stakeholder making the judgement (e.g. their skills, experience and expertise).

When looking from a stakeholder participant perspective, it is not possible to characterise which stakeholders express greater levels of uncertainty across (or within) stages of the design process. This shows that values could drive emergent and multistakeholder project stakeholder sensemaking under knowledge uncertainty.

The LEA client (stakeholder ' $h$ ') and the sustainability advisory group ('l') reported greatest levels of uncertainty. The former stated 8 times that they needed more information (across 6 criteria), while the latter was uncertain 8 times on 4 criteria. Both these stakeholders are highly experienced and have reviewed similar projects across a programme of projects, both are within the client organisation and both are central to briefing, policy setting and compliance checking. It is interesting that stakeholders with greater responsibility on the client side (who were not directly in the design team) often expressed greater value uncertainty (stakeholder ' $h$ ', 'j', 'l', and 'e' expressed 8, 7, 7 and 4 uncertainties, while those within the core team such as ' $\mathrm{i}$ ' and ' $\mathrm{k}$ ' expressed 2 and 1 uncertainties in value judgement where these were due to lack of client side information). More remotely involved and consulted stakeholders such as 'a', 'b', 'c' and 'g' expressed considerably less uncertainty $(0,0,3$, and 3$)$.

The school practitioner 'f' had 1 and school leadership 'e' had 4 uncertain judgements. This would intuitively suggest that those stakeholder participants that are most removed from the core design team could have lower or higher levels of uncertainty (depending on their responsibility in assuring the projects overall value); while those in the core team have certainty because they are directing the development of design information. In terms of sensemaking uncertainty may create sub-cultures, unless clear lines of communication build alignment and sense around a common core purpose.

\section{Universal values support abductive reasoning}

Table 3 shows that the triggered expressions of unique values could be most frequently (37 instances) ascribed to the universal values category 'Othersoriented' such as the uniquely triggered stakeholder values 'Collaboration' and 'Shar[ing]'. Unique stakeholder values also fell into 'Universalism' (20 times) and 'Achievement' (20 times). No unique 
values were triggered and associated with the 'Tradition' category, and 'Self-direction' and 'Power' were both poorly reflected with only 5 triggered unique values that could be intuitively grouped into these categories. This analysis reveals that the value criteria have different capacities to trigger these universal motivational values. The most values-rich criteria (criteria 20, 41, 12 and 35) have elicited unique values across a number of categories (60\%, $70 \%, 50 \%$ and $60 \%$ ), indicating a complex many to many relationship between value criteria and values types that make up culture (unique, shared, universal, espoused, aspirational, attributed or embedded). This may not be surprising considering the high proportion of stakeholders who selected these criteria $(5,5,7$, and 5 respectively). This may suggest that stakeholders bring a complex mix of unique values that are surfaced in dialogue, but the dynamic culture of a project is unlikely to reflect the full structure of universal values without provocation.

This finding indicates that there may be opportunities to understand the complex and dynamic nature of values as they drive sensemaking but this shows that it is very difficult to objectively characterise the values system of a project. As such the full engagement of all stakeholder representatives is a critical part of project management as a means of creating a values-rich and emergent view of a living, breathing and dynamic project. It conversely illustrates that limiting stakeholder involvement may have a negative effect on values triggering and hence on cultural socialization and the richness of interpretations.

[Insert Table 3 Here]

\section{There are complex values dialogues}

We now turn to the dialogues, and particularly the priorities, that arose in core project team meetings during the action research. These discussion arose naturally and were unstructured by any research and measurement instruments to define and assess value. Some relate to the issues reported in the previous two sections; however, they are more complex and show an interdependent picture of the multi-stakeholder values interpretations, reconciled in a single team decision. Further instances are likely to have been expressed in other design team meetings and informal interactions between stakeholders, as well as instances where values were implicit.

The impact of the stakeholders' values on design was evident, such as:

i. The size of a wind turbine was reduced from a sustainable and effective energy generator to a smaller and cheaper wind turbine, the main benefit of which was as a learning aid;

ii. The provision of an outside staff platform was justified on the basis of staff enjoyment/relaxation as well as the safety and supervision of children on site and during pick-up and drop-off; and 
iii. The delivery of a classroom that was flexible enough to deliver group and individual pedagogies and to reflect values of freedom and choice as well as control and order.

There were also instances of differences in stakeholder values priorities, that played out throughout design dialogue required the design team leadership to reconciled stakeholder views, for example:

i. Free flow, choice and personalised learning: A head teacher presented a vision for a school without doors, free access and pupil choice. The delivery team and client side education team considered this innovative proposal and put in place an adaptable strategy to facilitate it; however, a more traditional pedagogical design solution was implemented, with clear and controlled classroom access recorded by registered pupil movement.

ii. Provision of furniture for personalised learning: In order to stimulate more innovative teaching practices, a head teacher proposed fewer chairs than pupils in classrooms to ensure that pupils would move and sit in various positions, rather than around traditional working tables. These priorities were implemented, but not for subjects such as Maths and English, which were viewed by staff as desk-based. A more traditional (but still adaptable) classroom layout was provided for these subjects.

iii. Underfloor heating: There were concerns that underfloor heating may cause problems for floor based staff (often on their hands and knees); in the past some reported that under floor heating had caused swollen legs and fainting. Underfloor heating was a minimum requirement (as specified in the 'Red book') as it was efficient and reduced child accidents from trips, burns and climbing. To resolve this concern the client project manager procured heat reflecting mats for staff to work on the floor and the energy management team was consulted to reduce any safety concerns.

These examples reveal informal, emergent and trade-off dialogues that were a complex of values priorities and value requirements. This demonstrates the complex interaction between different sensemaking schemas in design.

As a result of the action research, the study played a direct part in the specification, though not necessarily the realisation, of some beneficial design features and qualities, including for example: 'the use of sub-metering zones'; 'An increase in storage space’; 'Improved operational statements’; ‘A waste and materials recycling storage area'; and 'Seating that combined with lighting at a low, medium and high level height for mixed pedagogy and 
personalised learning'. Therefore, although the values system is important in delivering stakeholder satisfaction and learning, it should also be recognised that its contribution to value delivery is partial. Other policy documents such as the 'Red book' played a more critical role in the emergence of design information (and formed the basis for quality assurance, approval and compliance checking).

\section{Discussion}

\section{A complex and emerging inter-relationship}

\section{between value and values}

It was shown that stakeholders expressed unique values during emerging design and made unique assessments of value. This may empirically confirm Green and Simisiter's (1999) view that a client is not ‘unitary’ and that approaches that force stakeholders to consider common goals, may be a façade to the reality of the emerging and dynamic project system.

Stakeholder 'e' was better placed to understand embedded and aspirational values gaps and so espouse and reconcile various perspectives/schemas through sensemaking (Weick et al., 2005) and sensegiving (Gioia and Chittipeddi, 1991) and embed their values within a culture. This is because people are guided by what leaders pay attention to, measure and control (Schein, 2004) and through transformational leadership (Ciulla, 1994) that transfers individual and organisational means- and ends- values from leaders to employees to increase their understanding of task importance.

Values (in all their forms; e.g. unique, universal, espoused) provided a useful schema and convenient theoretical device as in Harris $(1984,1989)$ for individuals to share and socially validate outcomes and behaviours. Empirical findings showed that there was a complex expression of values. Stakeholders' frames changed over time (as demonstrated in the relationship between perceived experience, expectations and judged satisfaction).

All of Harris (1994), five categories of inorganization schemas involved in sensemaking were elicited. With stakeholder participants subscribing to values themselves, or ascribing values to others, to some organizational or wider group, or other object/concept and events. Taken together, the empirical data has demonstrated various individual ways of make sense of the design process.

\section{A dynamic perspective of the emerging project}

\section{values culture during design}

The number of stakeholders participating in a project will most likely increase the volume and diversity of unique values triggered and, hence, the greater variation in perspectives and judgements. This supports the view of an emerging value system and provides a more nuanced description of what is meant by 'value culture', 'value sensemaking', 'value thread' and 'value flux' to describe the dynamic 
nature of project value (British Standards Institute, 2000; Thiry, 2001; Kelly et al., 2004; Male et al., 2007).

In order to illustrate the point, we hypothesise two views of the emergence of project value and values systems (Figure 6). The first is associated with the common problem of late, misunderstood, disruptive and self-oriented stakeholder value and values systems alignment. The second is an ideal view of individuals' values nested and aligned within a broader organisational and societal value-values system.

Figure 6, shows interacting plectrum shapes to represent judgements and the numbers i - vii are related to the opportunities for value-values cocreation previously defined (Figure 1c). What Figure 6a shows is a lack of alignment (as represented by the chaotic and disrupted interaction of plectrum shapes). In this situation, there may be an over emphasised focus on the client's value and values system alone, with limited involvement of wider stakeholders, inadequate sensemaking and poor management of their expectations. Delayed stakeholder involvement limits opportunities for the development of relationships, lack of value and values sensemaking and poor individual-project alignment. Instead, stakeholders may see only their own expectations (or 'targets') without compromise and make unrealistic value judgements, driven by their personal expectations and unique values rather than the combined experience of the group. As a result, less involved stakeholders perceive more sacrifices. Furthermore, late involvement may prevent the expression of values so compromises may be experienced more deeply and not understood against a wider project vision.

Values are more likely to vary in projects than in organizations because of the diversity of stakeholders. Differing unique values will be espoused and attributed, but not shared with individuals taking differing values perspectives. For Bourne and Jenkins (2013) '...convergence around shared values [is unlikely]...because of the proximity of members and the frequency with which they interact' (p. 501).

\section{[Insert Figure 6 Here]}

Stakeholder value judgements emerged with the development of design information, which often preceded the ability of a stakeholder to make value judgements, but the reverse may be true of the expression of values. Values triggering appeared to happen earlier in the design process, when less design information was available. Unique values elicitation appears to be easier in the project front-end. The discussion of values at this early stage is also highly beneficial; it motivates engagement, stimulates creativity and focusses wider stakeholder participants on the building operation and service delivery, rather than a singular focus on the physical qualities of the building (i.e. the generation of a wish list as in Luck et al. (2001)). 
Much like Sage et al. (2010) described, the 'Red book' was the source of compliance and control in the sense of a boundary spanning object. VALiD played an important part in orchestrating social relations by presenting, in small manageable chunks, the content of the Red book and in eliciting subjective and contextual interpretations of it. The approach applied in this study built sense, and helped the dynamic interrelationship between stakeholders. In addition it provided knowledge on their satisfaction and homogeneity in terms of value and values. This is aligned with Neill et al. (2007) view of sensemaking as a capability that enables adaptation and the absorption of complexity.

The grounded and emerging situation observed in this study is supportive of Mintberg's (1978) view of strategy as 'pattern[s] in streams of decisions', Swinder's (1986) view of culture as a 'toolkit in action', and Weick's view of 'organizing', 'sensemaking' and 'loose coupling' (Weick, 1979; Daft and Weick 1984 and Weick et al., 2005). It moves beyond a consideration of simple and monolithic values alone (Waterman et al. 1980), to the need to understand and perhaps untagle a complex of unique, situated and neauced stakeholder value and values relationships. But then what about the role for universal values.

It is no surprise that most unique stakeholder values were triggered and associated with 'othersoriented', ‘universalism' and ‘achievement' SVS domains as concepts such as these (e.g. sustainability, responsibility, collaboration, integration and learning) are high in practitioners' collective cognition and high on the value agenda (Thomson et al., 2013). Although a more rounded and dynamic picture of the whole value and values system is needed to create and maintain strong leadership in the establishment and maintenance of culture (Schein, 2004), and to inform participation and socialization (Hofstede, 1998; Baines, 1998).

\section{A new role for universal values in supporting nested sensemaking and sensegiving}

What is certain is that unique values can be triggered through dialogue, so the application of a standardised universal framework of values (such as Schwartz), is not always necessary. However, inductive triggering of unique values does not consider the broadest array of values, nor can their relative importance be prioritised.

Universal values instruments such as the SVS are self-orientated. But values are also uniquely expressed in a dynamic fashion in relation to many more entities than the self. This confirmed Bourne and Jenkins (2013) view of dynamic values and the schema-based perspective presented by Harris (1989, 1994).

Better understanding of universal values will almost certainly provide a cultural bridge to align individuals and organizations on projects. This study has shown that it is important to combine both unique 
values elicitation with the assessment of universal values in order to give greater clarity, richness and academic rigour to results.

Values could support sensemaking and sensegiving through demonstrating a broader frame of interests and conceiving values that go beyond financial value and enable the alignment and tracking of stakeholder satisfaction (Mittal and Lassar, 1998; Kärnä et al., 2013).

Figure $6 \mathrm{~b}$ illustrates the ideal hypothesis where there is greater adaptation, learning and socialization, and a nested order to the value and values system through emergent understanding and sensemaking that is understood in part using universal values. In this view the role of the project manager is to reconcile stakeholder perspectives and to nest and embed individuals within a project climate and beyond.

In this hypothesised view there is more likely to be concerted effort to mesh the experience and expectations of all parties. Project managers may then routinely manage relationships that deliver value without unduly compromising deep values. Furthermore, the greater alignment of value and values may motivate people and greater innovation may result.

Sagiv and Schwartz (2007) conceptualized the importance of values to help organizations to be ‘nested within societies'. This view must be combined with wider knowledge, business and market based systems such as Bartunek's et al. (1999) view of culture as a guide for sensemaking and emerging individual schemas established through scaning the internal and external environment. In addition, Daft and Weick's (1984) view organizations as 'interpretation systems' and the co-creation of market systems (Vargo et al., 2008 and Vargo, 2011). This article provides knowledge on the emergence of unique values and presents a dynamic perspective of a project culture that enables the alignment of individuals, organisations and communities.

\section{Limitations}

The empirical findings have captured only a snapshot of the project's complexity, the full implications of the dynamic and shifting nature of values may never be fully understood.

The researcher was not values-neautral in this process of elicitation and judgement. The application of grounded theory and action research may have resulted in some researcher-induced bias and reapplication difficulties; however these limitations were minimised by strong industry collaboration and validation. Charmaz (2006) states that personal influences on value systems must be accepted and that methods such as Orton’s (1997) ‘iterative grounded theory’ must be applied to deal with complexity, loose coupling, learning, culture, decision making and change. In this sense this research supports Weick's (1969) view of '...dynamic organisational processes’ 
and Argyris and Schön (1978, 1989) expressed need for 'action learning'.

The categorization of stakeholder participant unique values into universal values categories (table 1 and 3) is somewhat subjective. The results are therefore more discursive than conclusive. Whilst the validity of this intuitive categorization by the authors might be challenged on the basis that it is normative, generic and irrelevant to understanding the dynamics of values in project climate, Schwartz himself has provided significant empirical and statistical validity for the universal application of this framework. Moreover our own work (Mills et al., 2009) provides further justification and empirical validity. As to whether this framework is suitable for a project environment, the emphasis here is in developing the scientific exploration of values in the project management field. Without a theoretical position, and set of robust measures it is unlikely that we will be able to extent the rigour and evidence in classifying the nature of the design process and its subsequent management on projects. This is not to say that this is the only theoretical lens from which we could view the project environment; on the contrary the authors believe that pluralistic theoretical perspectives are needed to understand the complex nature of projects from various socio-technical and cultural perspectives.

\section{Conclusions}

This work has addressed the lack of focus on individual stakeholder sensemaking in the understanding of an emerging project culture. The emergent, complex and dynamic nature of a cultural value and values system is understood on a longitudinal case study to demonstrate multiple stakeholders perceptions.

Empirical data was gathered through action research and using value in design (VALiD) to structure stakeholder dialogues at three interventions in the briefing and design stages of a new primary school project over a two year period. Schwartz's (1992) theory of human values was subsequently used to theoretically triangulate and postulate on the emergence of unique stakeholder values.

The findings contribute new insights into the complex and emerging inter-relationship between stakeholder value and values systems. It provides a dynamic perspective of a project culture and challenges the role of universal values in supporting sensemaking.

Broader values awareness and concerted sensemaking and socialization efforts may contribute to long-term relationships and increased value. To achieve this will require greater cultural sensitivity among stakeholder participants in order that individuals will be able to align and embed values within nested and emerging systems. 


\section{Acknowledgements}

The 'Managing Value Delivery in Design' study was undertaken at Loughborough University, UK. The work was conducted in the Innovative Manufacturing and Construction Research Centre (IMCRC) and was funded by the EPSRC and the DTI under grant numbers GR/R64490/01 and 39/12/16 cc2323 respectively. The authors acknowledge the extensive support of the Department of Civil and Building Engineering at Loughborough University, AMEC, Arup, BAA, Broadgate Estates Limited, CABE, CIBSE, Constructing Excellence, Davis Langdon LLP, Manchester City Council, Sheppard Robson and the RICS Research Foundation. Key findings were launched to the industry in July 2005 and are available at www.valueindesign.com. The principles have been deployed in industry and developed through ongoing research. The opportunity presented as part of the ESRC culture perspectives and projects series and the keynote presentation made by Professor Simon Austin to raise the issue of 'stakeholders achieving value on projects’ are also acknowledged.

\section{References}

Argyris, C. and Schön, D. (1978) Organizational learning. A theory of action and perspective. Reading, PA: Addison-Wesley.

Argyris, C. and Schön, D. (1989) Participatory action research and action science compared: A commentary. American behavioral scientist.

Arnstein, S.R. (1969) A ladder of citizen participation. Journal of the American Planning Association, 35(4), 216-24.
Attwood, M., Pedler, M., Pritchard, S. and Wilkinson, D. (2003) Leading change: A guide to whole systems working. Bristol, UK: The Policy Press.

Austin, S., Baldwin, A., Hammond, J., Murray, M., Root, D.S. and Thorpe, A. (2001) Design chains: A handbook for integrated collaborative design. Loughborough: Thomas Telford.

Austin, S.A., Thomson, D.S. and Mills, G.R. (cited 2008) Value in design (valid). [Available online from www.valueindesign.com/.].

Baines, A. (1998) Creating a culture of ownership. Work Study, 47(1), 14-6.

Bardi, A. and Schwartz, S.H. (2003) Values and behaviours: Strength and structure of relations. Personality and Social Psychology Bulletin, 29(10), 1207-1220.

Barlow, J. and Jashapara, A. (1998) Organisational learning and inter-firm partnering in the uk construction industry. The Learning Organisation, 5(2), 86-98.

Bartunek, J., Krim, R. M., Necochea, R., and Humphries, M. (1999) Sesnsemaking, Sensegiving, and Leadership in Strategic Organizational Development. Advances in Qualitative Organizational Research. 2, 37-71.

Bishop, M., Tyson, L., Brittan, S., Mayo, E. and Vallence, L. (2003) Shareholders vs. Stakeholders. RSA Lecture in association with The Economist.

Bourne, H and Jenkins, M. (2013) Organizational Values: A dynamic perspective, Organizational Studies. 34(4): 495-514.

British Standards Institute (2000) Pd 6663: Guidelines to bs en 12973: Value management practical guidance to its use and intent BS EN 12973, London: British Standards Institute.

Bresnen, M., Goussevskaia, A. and Swan, J. (2005) Managing projects as complex social settings, Building Research and Information, 33(6), 487493.

Brown, M.A. (1976) Values - a necessary but neglected ingredient of motivation on the job. Academy of Management Review, 1(1), 15-23.

Brown, J. S., and Duguid, P. (1991). Organizational learning and communities-of-practice: Toward a unified view of working, learning, and innovation. Organization Science, 2(1), 40-57.

Brown, J. S., and Duguid, P. (1998). Organizing knowledge. California Management Review, 40(3), 90-111.

Brown, J. S., and Duguid, P. (2001). Knowledge and organization: A social-practice perspective. Organization Science, 12(2), 198-213.

Bucciarelli, L.L., (2002) Between thought and object in engineering design, Design Studies, 23(3), pp219-231.

Ciulla, J.B. (1999) The importance of leadership in shaping business values. Long Range Planning 32(2): 166-172. 
Christensen, G. L. and Olson, J. C. (2002) Mapping Consumers' Mental Models with ZMET. Psychology \& Marketing. 19: 477-502.

Daft, R.L, and Weick, K.E. (1984) Toward a Model of Organizations as Interpretation Systems. The Academy of Management Review 9(2): 284-295.

Dainty, A.R.J., Bryman, A., Price, A.D.F, Greasley, K., Soetanto, R. and King, N. (2005) Project affinity: The role of emotional attachment in construction projects. Construction Management and Economics, 23(3), 241-4.

Dallas, M. and Humphrey, S. (2004) Value or cost. The Value Manager, 10(1), 11-4.

Davies A., Brady, T., Hobday, M. (2006) Charting a path towardsintegrated solutions, MIT Sloan Management Review, 47(3), 39-48.

Davies A., Gann, D. and Douglas, T. (2009) Innovation in Megaprojects: Systems integration at london heathrow terminal 5, California Management Review, 51(2), 101-.

Desjardins, N. M. (2002) A case study in organizational value communication: Understanding value/behaviour relationship. In: Central Connecticut State University: Master's Thesis, Department of Communication, 1-58.

Drummond, J. and Themessl-Huber, M. (2007) The cyclical process of action research: The contribution of Gilles Deleuze. Action Research 5(4) 430-448.

Edkins, A., Geraldi, J., Morris, P. and Smith, A. (2013) Exploring the front-end of project management. The Engineering Project Organization Journal, 3(2), 71-85.

Emmitt, S., Sander, D. and Christoffersen, A.K. (2005) The value universe: Defining a value based approach to lean construction. In: Proceedings IGLC-13, Sydney, Australia: IGLC, 57-64.

Fellows, R. and Liu, A.M.M. (2013) Use and misuse of the concept of culture. Construction Management and Economics, 31(5), 401-422.

Fernie, S. and Thorpe, A. (2007) Exploring change in construction: Supply chain management. Engineering, Construction and Architectural Management, 14(4), 319-33.

Freeman, R.E. (1984) Strategic management: A stakeholder approach. Boston: Pitman.

Freeman, R.E., Wicks, A.C. and Parmar, B. (2004) Stakeholder theory and 'the corporate objective revisited'. Organization Science, 15(3), 364-9.

Gaver, W., Dunne, A. and Pacenti, E. (1999) Cultural probes, Interactions, 6(1), 21-29.

Gaver, W.W., Boucher, A., Pennington, S. and Walker, B. (2004) Cultural probes and the value of uncertainty. Interactions 11(5) 53-56.

Gioia, D.A., and Chittipeddi, K. (1991). Sensemaking and sensegiving in strategic change initiation. Strategic Management Journal, 12, 433-448.
Grant, R. M. (1996) Towards a Knowledge-Based Theory of the Firm. Strategic Management Journal 17: 109-122.

Green, S. D. and Simisiter, S. J. (1999) Modelling Client Business Processes as an Aid to Strategic Briefing. Construction Management and Economics 17: pp. 63-76.

Green, S.D., Fernie, S. and Weller, S. (2005) Making sense of supply chain management: A comparative study of aerospace and construction. Construction Management and Economics, 23, 579-93.

Greenwood, D.J and Levin, M. (2007) Introduction to action research: Social research for social change. London: Sage Publications.

Grönroos, C. and Vaima, P. (2012) Critical service logic: Making sense of value creation and cocreation. Journal of the Academic Marketing Society, 41(2) 133-50.

Harris, S. G. (1989) A Schema-Based Perspective on Organizational Culture. Academy of Management Proceedings, August, 1: 178-182.

Harris, S.G. (1994) Organizational culture and individual sensemaking: A schema-based perspective. Organization Science, 5(3), 309-21.

Hasan, H. (1999) The mediating role of technology in making sense of information in a knowledgeintensive industry. Knowledge and Process Management, 6(2), 72-82.

Hasan, H. and Gould, E. (2001) Support for the sensemaking activity of managers. Decision Support Systems, 31(1), 71-86.

Helkkula, A., Kelleher, C. and Pihlström, M. (2012) Characterizing value as an experience: Implications for service researchers and managers. Journal of Service Research, 15(1), 5975.

Henderson, J.R., Ruikar, K.D. and Dainty, A.R.J. (2013) The need to improve double-loop learning and design-construction feedback loops. Engineering, Construction and Architectural Management, 20(3), 290-306.

Hillman, A.J. and Keim, G.D. (2001) Shareholder value, stakeholder management and social issues: What's the bottom line? . Strategic Management Journal, 22(2), 125-39.

Hitlin, S. and Piliavin, J.A. (2004) Values: Reviving a dormant concept. Annual Reviews of Sociology, 30, 359-93.

Hofstede, G. (1998) Attitudes, values and organisational cultures: Disentangling the concepts. Organization Studies, 19(3), 477-92.

Jaffe, D.T. (1998) How to link personal values with team value. Training and Development, March, 24-30.

Johnstone, S., Dainty, A. and Wilkinson, A. (2009) Integrating products and services through life: An aerospace experience. International Journal of Operations and Production Management, 29(5), 520-38. 
Jones, I.W. and Pollitt, M.G. (1999) Putting values into action: Lessons from best practice. Long Range Planning, 32(2), 162-5.

Kärnä, S., Junnonena, J-M., Manninena, A-P., Julinb, P. (2013) Exploring project participants satisfaction in the infrastructure projects, Engineering Project Organization Journal, 3(4), 186-197.

Kelly, J., Steve, M. and Drummond, G. (2004) Value management of construction projects. Oxford: Blackwell Science Ltd.

Kelly, J. (2007) Making client values explicit in value management workshops. Construction Management and Economics, 25(April), 435-42.

Kirk, S.J. and Spreckelmeyer, K.F. (1988) Creative design decisions: A systematic approach to problem solving in architecture. New York: Van Nostrand Reinhold.

Kotter, J. and Heskett, J. (1992) Corporate culture and performance. Free Press.

Lepak, D.P., Smith, K.G. and Taylor, M.S. (2007) Value creation and value capture: A multilevel perspective. Academy of Management Review, 32(1), 180-94.

Lera, S.G. (1981) Empirical and theoretical studies of design judgement: a review, Design Studies, 2(1), 19-26.

Leung, M-Y and Liu, A.M.M (2003) Analysis of value and project goal specificity in value management. Construction Management and Economics, 21(1), 11-9.

Luck, R., Haenlein, H. and Bright, K. (2001) Project briefing for accessible design. Design Studies 22(3), 297-315

Luck, R., (2012) Editorial: 'Doing designing': On the practical analysis of design in practice. Design Studies 33(6), 521-529.

Male, S. (1991) Competitive advantage in construction. Oxford: Butterworth-Heineman.

Male, S., Kelly, J., Gronqvist, M. and Graham, D. (2007) Managing value as a management style for projects. International Journal of Project Management, 25(2), 107-14.

McGeorge, D., Palmer, A. (1997) Value management. In: Mcgeorge, D, Palmer, A. (Ed.), Construction management: New directions, pp. 11-52. Oxford: Blackwell Science.

Mills, G.R.W, Austin, S.A., Thomson, D.S. and Devine-Wright, H. (2009) Applying a universal content and structure of values in construction management. Journal of Business Ethics, 90(4), 473-501.

Mills, G.R.W (2013) Values and value in design, Doctoral thesis, School of Civil and Building Engineering, Loughborough University.

Mintzberg, H. (1978) Patterns in Strategy Formation, Management Science, 24(9), 934-948.

Mittal, B. and Lassar, W.M. (1998) Why do customers switch? The dynamics of satisfaction versus loyalty. The Journal of Services Marketing, 12(3), 177-94.

Morrey, N., Dainty, A.R.J. and Pasquire, C.L. (2013) Developing a strategy to enact lean. Journal of Engineering, Project, and Production Management, 3(1), 35-45.

Morris, P. and Hough, G.H. (1988) The anatomy of major projects: A study of the reality of project management. Chicester: John Wiley and Sons.

Morris, P (2013) Reconstructing project management. Chicester: Wiley-Blackwell.

Neill, S., McKee, D. and Rose, G.M. (2007) Developing the organization's sensemaking capability: Precursor to an adaptive strategic marketing response. Industrial Marketing Management, 36(6), 731-44.

Newell, A., Shaw, J. C. \& and Simon, H. A. (1959) Report on a general problem-solving program, Proceedings of the International Conference on Information Processing. 256-264,

Newell, A. and Simon, H. A. (1972) Human problem solving, NJ, Englewood Cliffs. Prentice-Hall

Nicolini, D. (2002) In search of 'project chemistry'. Construction Management and Economics, 20(2), 167-7.

Normann, R. and Ramirez, R. (1993) From value chain to value constellation: Designing interactive strategy. Harvard Business Review, Jul-Aug, 71(4):65-77.

Orton, J.D. (1997) From inductive to iterative grounded theory: Zipping the gap between process theory and process data. Scandinavian Journal of Management, 13(4), 419-38.

Ott, J. S. (1989), The Organizational Culture Perspective, Chicago, IL: The Dorsey Press.

Payne, A. and Holt, S. (2001) Diagnosing customer value: Integrating the value process and relationship marketing. British Journal of Management, 12(2), 159-82.

Peat, R. (2003) Values drive value. University of Auckland, Business Review, 5(2), 1-11.

Perminova, O., Gustafsson, M. and Wikstrom, K. (2008) Defining Uncertainty in Projects - A new perspective. International Journal of Project Management: Special Issue 26(1): 73-79.

Pryke, S. and Smyth, H. (2006) The Management of Complex Projects: A Relationship Approach, Chicester: Wiley-Blackwell.

Rescher, N. (1969) Introduction to value theory. New York: Prentice Hall.

Sage, D.J., Dainty, A.R.J. and Brookes, N.J. (2010) Who reads the project file? Exploring the power effects of knowledge tools in construction project management, 28, 629-239.

Sagiv, L. and Schwartz, S. H. (2007) Cultural values in organisations: Insights for europe. European Journal of International Management 1(3): 176190.

Sawhney, M. (2002) Create value from values. CIO Magazine, Nov 15. 
Schein, E.H. (2004) Organizational culture and leadership. Vol. 3rd Edition, Business and mangement series, San Francisco: Jossey-Bass (Wiley Imprint).

Schwartz, S.H. (1987) Toward a universal psychological structure of human values. Journal of Personality and Social Psychology 53(3): 550562.

Schwartz, S.H. (1992) Universals in the content and structure of values: Theoretical advances and empirical tests in 20 countries. Advances in Experimental Social Psychology, 25, 1-65.

Schwartz, S.H. and Boehnke, K. (2004) Evaluating the structure of human values with confirmatory factor analysis. Journal of Research in Personality, 38(3): 230-255.

Schwartz, S.H. (2005) Basic human values: Their content and structure across cultures. In: Tamayo, A and Porto, J.B. (Eds.), Valores $e$ comportamento nas organizações [values and behavior in organizations], pp. 21-55. Brazil: Vozes.: Petrópolis.

Sherman, H.J.S, (1998) Open boundaries: Creating business innovation through complexity. Reading, MA: Perseus Books.

Skitmore, M. and Smyth, H. (2007) Pricing construction work: A marketing viewpoint. Construction Management and Economics, 25(6), 619-30.

Smith, J. (2002) Strategic client briefing: Stakeholder experience. In, COBRA 2002, Proceedings of the RICS Foundation construction and building research conference, 5-6 September, Nottingham Trent University.

Strategic Forum for Construction (2002) Accelerating change, London: Strategic Forum.

Susman, G.I, (Ed. (1983) Action research: A sociotechnical systems perspective. London: Sage Publications.

Susman, G.I and Evered, R.D (1978) An assessment of the scientific merits of action research. Administrative Science Quarterly, 23(4), 582-603.

Swindler, A. (1986) Culture in action: Symbols and strategies. American Sociological Review, 51(April), 273-86.

Tennant, S. and Fernie, S. (2013) Organisational learning in construction supply chains. Engineering Construction and Architectural Management, 20(1), .83-98.

Thiry, M. (2001) Sensemaking in value management practice. International Journal of Project Management, 19(2), 71-77.

Thomson, D.S., Austin, S.A., Devine-Wright, H. and Mills, G.R. (2003) Managing value and quality in design. Building Research and Information, 31(5), 334-45.

Thomson, D. (2011) A pilot study of client complexity, emergent requirements and stakeholder perceptions of project success.
Construction Management and Economics, 29(1), 69-82.

Thomson, D.S., Austin, S.A. and Mills, G.R. (2013) Practitioner understanding of value in the UK building sector. Engineering, Construction and Architectural Management, 20(3), 214-231.

Vargo, S.L., Maglio, P.P. and Akaka, M.A. (2008) On value and value co-creation: A service systems and service logic perspective. European Management Journal, 26, 145-52.

Vargo, S.L. (2011) Market systems, stakeholders and value propositions Toward a service-dominant logic-based theory of the market. European Journal of Marketing, 45(1/2): 217-222.

Van Maanen, J. (1976), Breaking-in: Socialization to Work, in R. Dubin (Ed.), Handbook of Work, Organization, and Society, Chicago, IL: Rand McNally, 67-130.

Van Maanen, J. and S. R. Barley (1985) Cultural Organization: Fragments of a Theory, in P. J. Frost, L. F. Moore, M. R. Louis, C. C. Lundberg, and J. Martin (Eds.), Organizational Culture, Beverly Hills, CA: Sage, 31-54.

Waterman, H., Tillen, D., Dickson, R. and De Koning, K. (2001) Action research: A systematic review and guidance for assessment. . Health Technology Assessment.

Waterman, R.H., Peters, T.J. and Phillips, J.R. (1980) Structure is not organization. Business Horizons, June, 14-26.

Weick, K.E. (1969) The social psychology of organizing. Reading, MA: Addison-Wesley.

Weick, K. E. (1979) Cognitive Processes in Organizations, in B. M. Staw (Ed.), Research in Organizational Behavior, Vol. 1, Greenwich, CT: JAI, 41-74.

Weick, K. E., Sutcliffe, K. and Obstfeld, D. (2005) Organizing and the process of sensemaking. Organization Science, 16(4), 409-421.

Wiener, Y. (1988) Forms of Value Systems: A focus on organizational effectiveness and cultural change and maintenance, Academy of Management Review, 13(4), 534-545.

Yin, R. (1994) Case Study Research: Design and methods, Beverly Hills, CA: Sage Publishing.

Zhang, X., Austin, S.A., Glass, J. and Mills, G.R. (2008) Toward collective organizational values: A case study in UK construction. Construction Management and Economics, 26(10), 1009-28. 


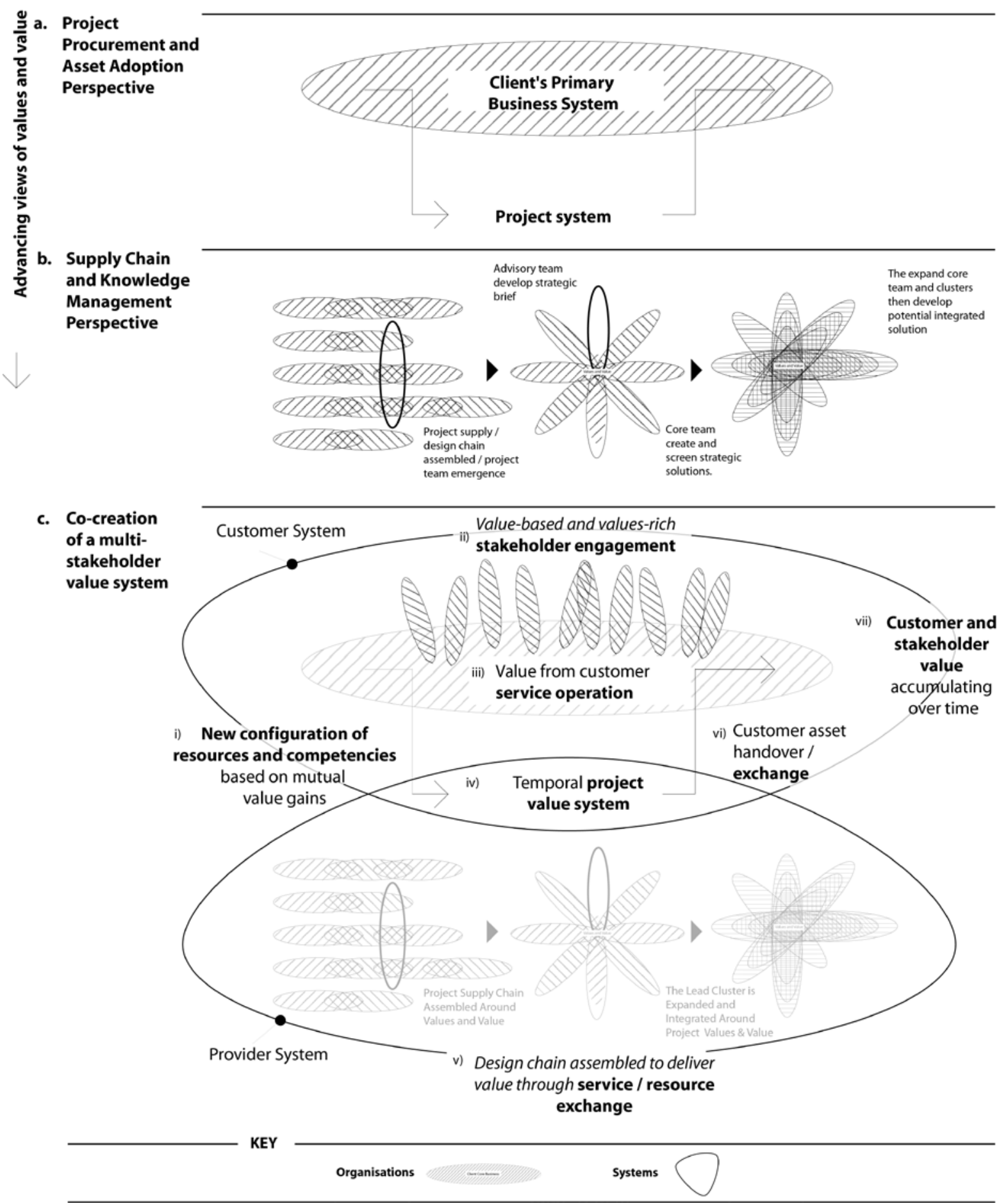

Figure 1: Mutual Interdependence in the Value-Values System 


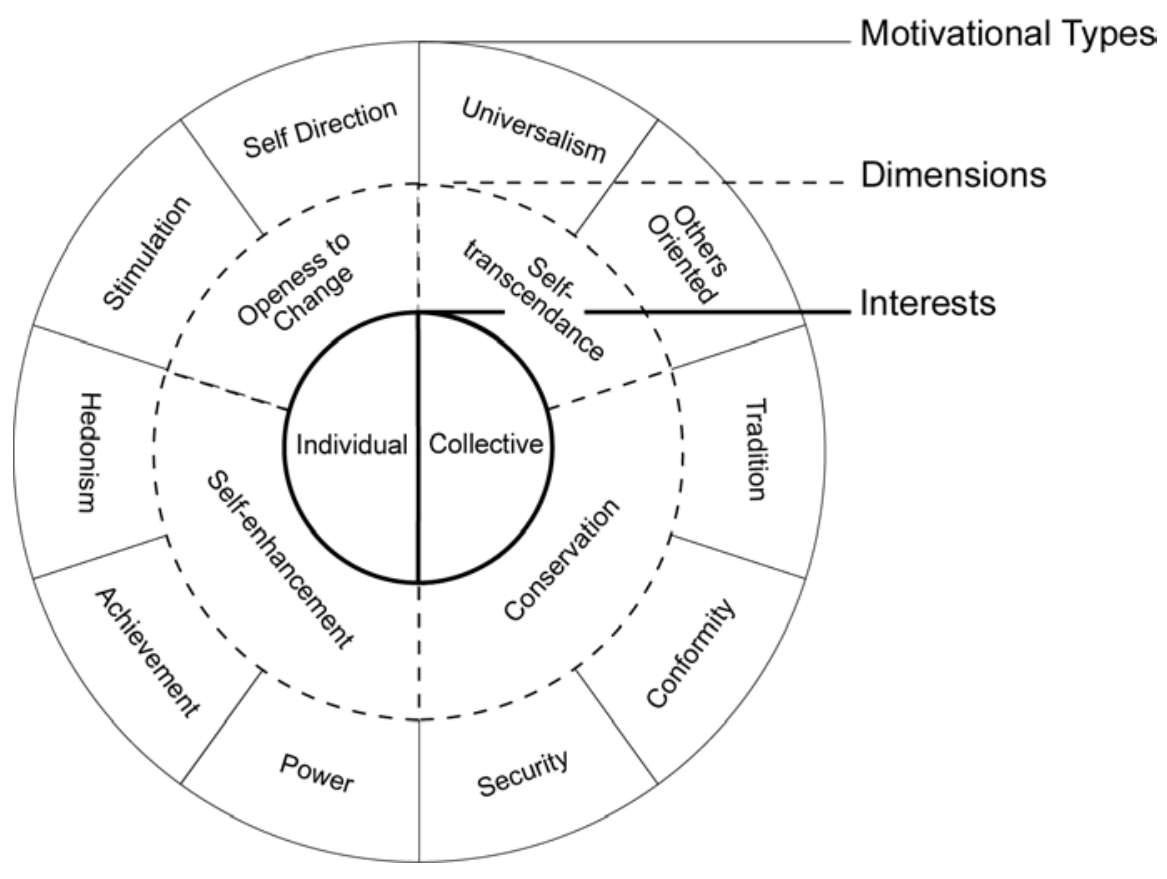

Figure 2. Theoretical model of relations among 10 Motivational types of Values, Adapted from (Schwartz and Boehnke 2003).

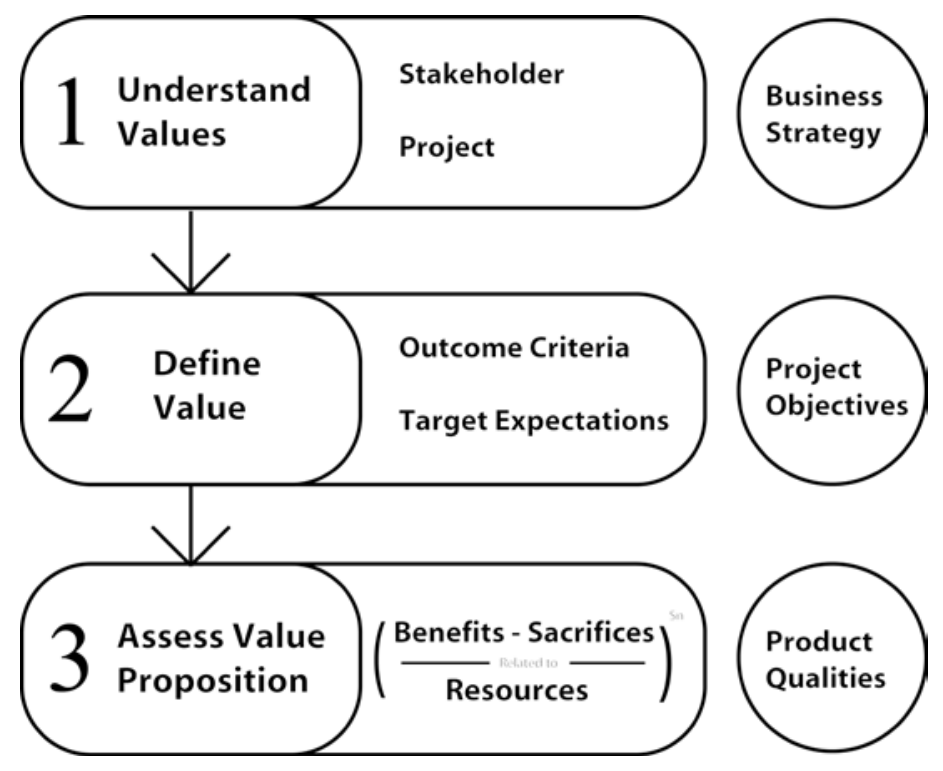

Figure 3: The VALiD Framework and Equation 
i) Value When Assessed Against Target Expectation
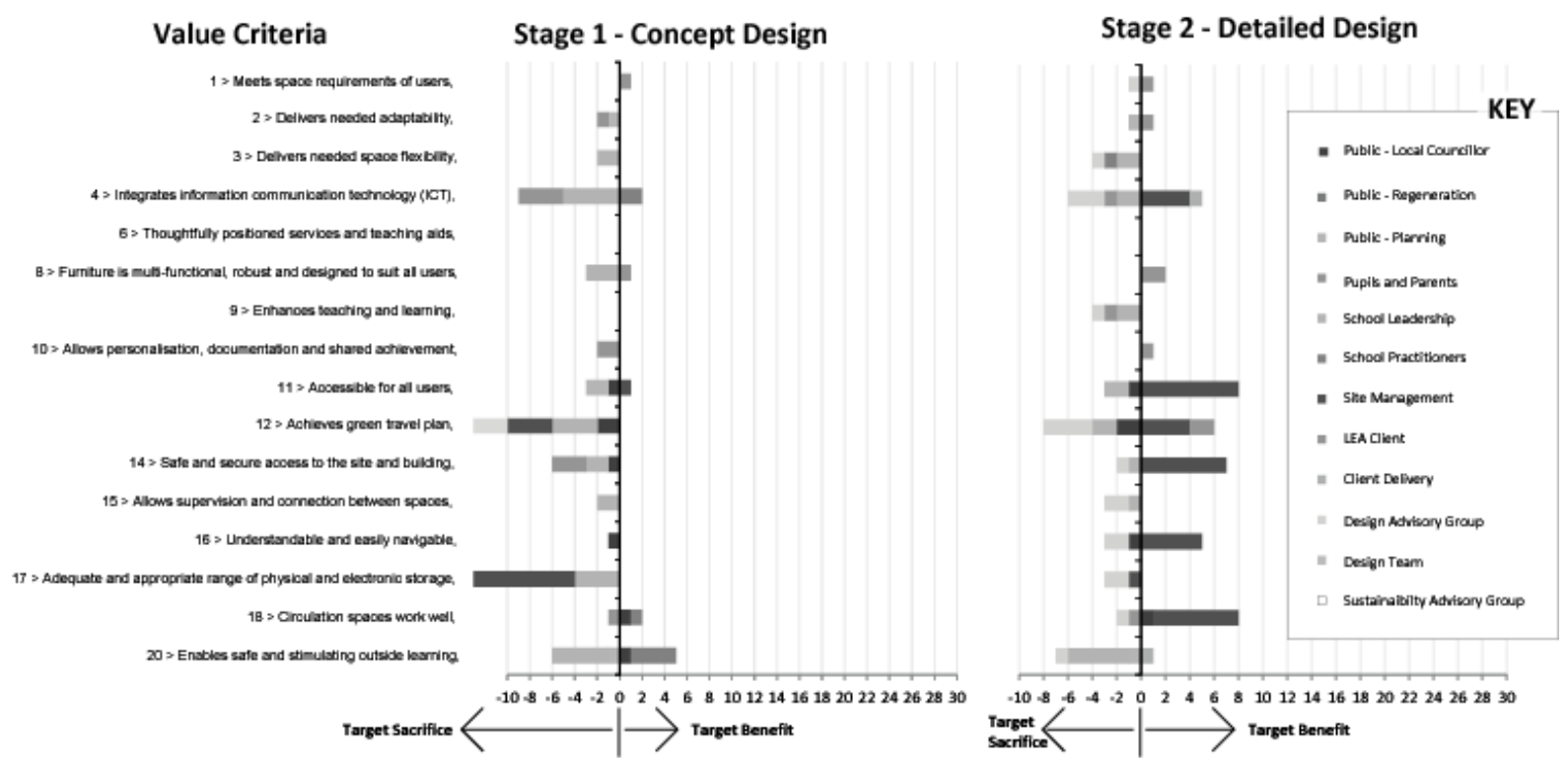

ii) Value When Assessed Against Present Experience
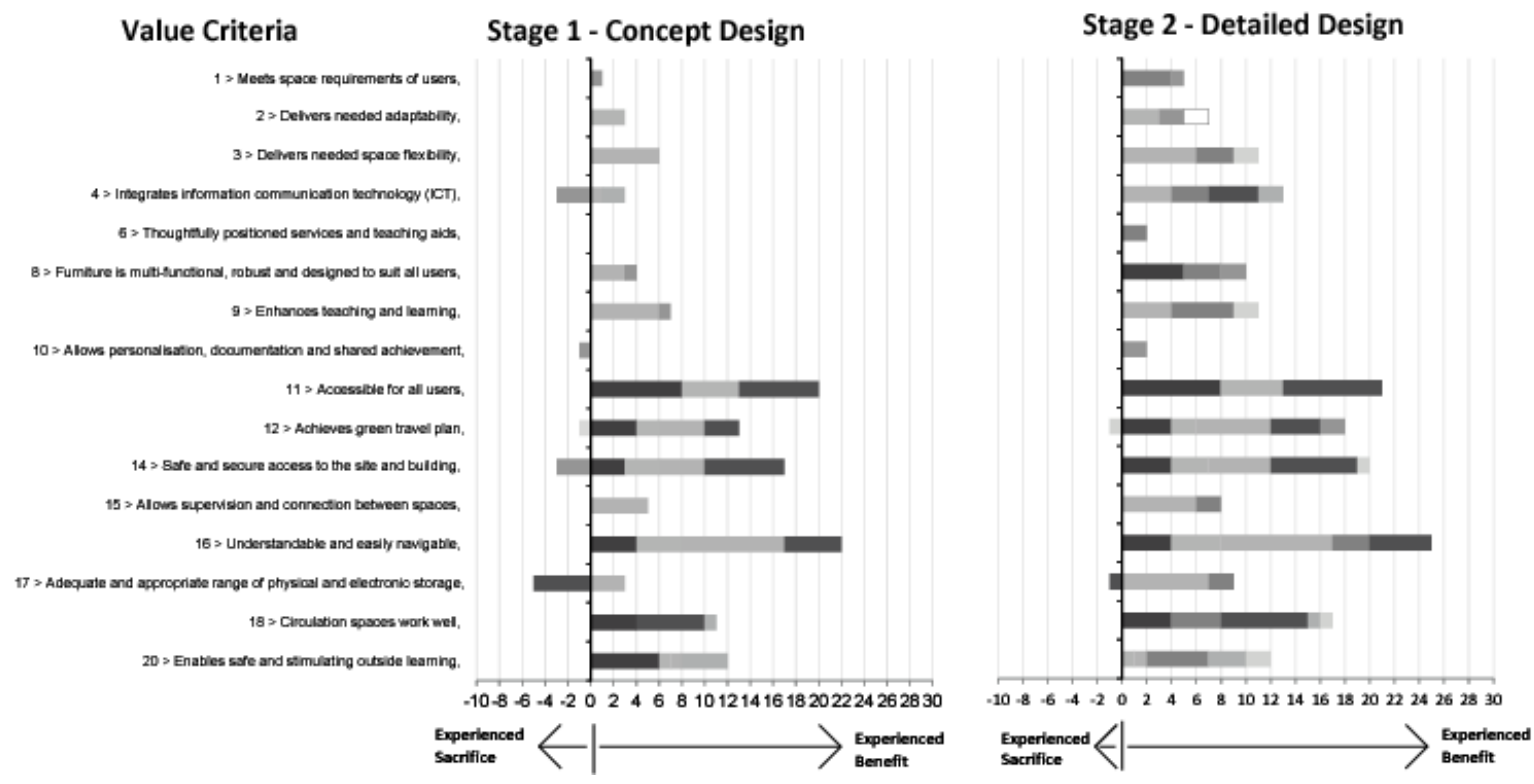

Figure 4. Example of 'Functionality' Dashboard, showing multi-stakeholder value (benefits and sacrifices) at concept (1) and detailed design (2) stages 


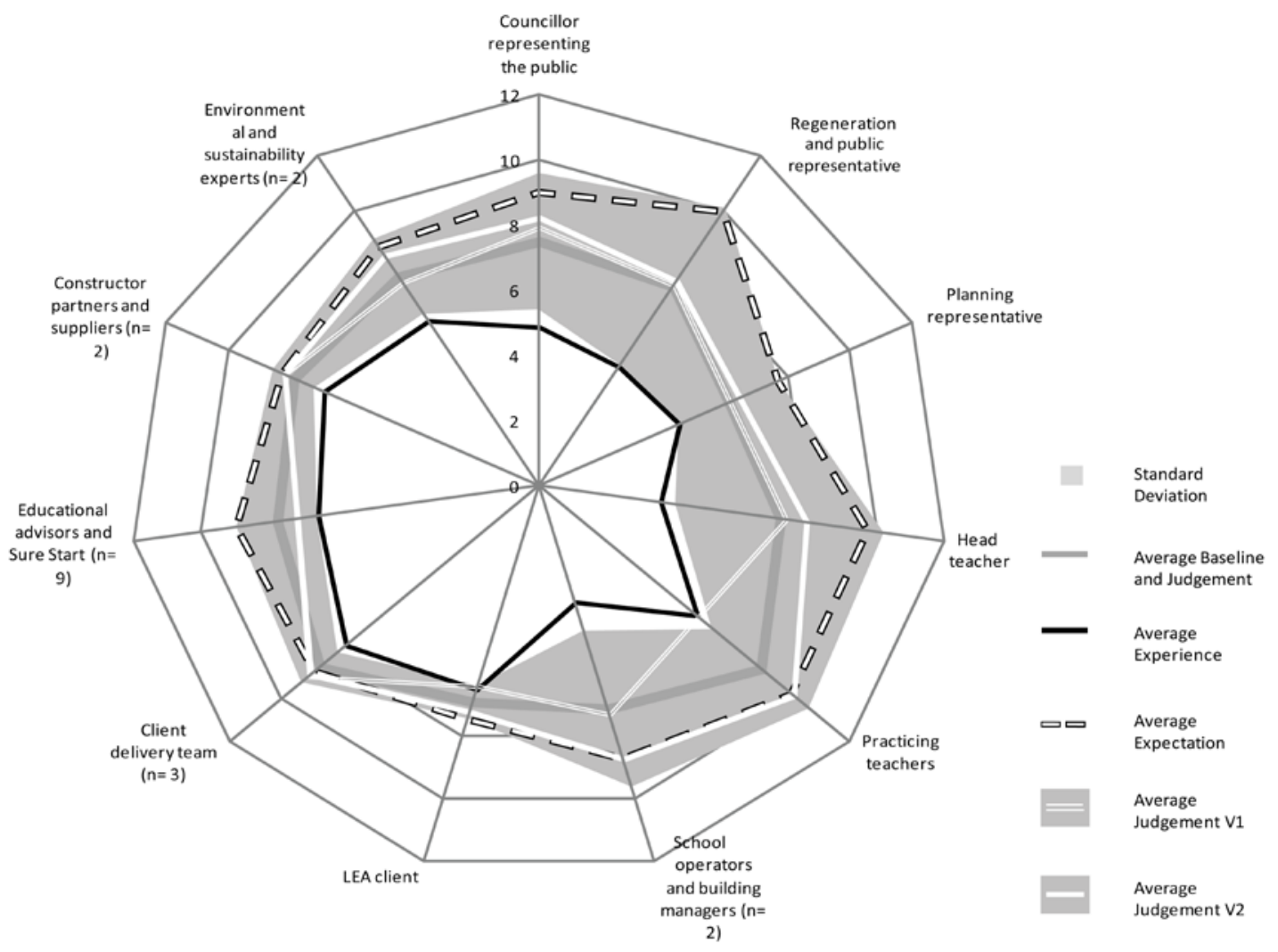

Figure 5 Stakeholder average criteria baselines and judgements 


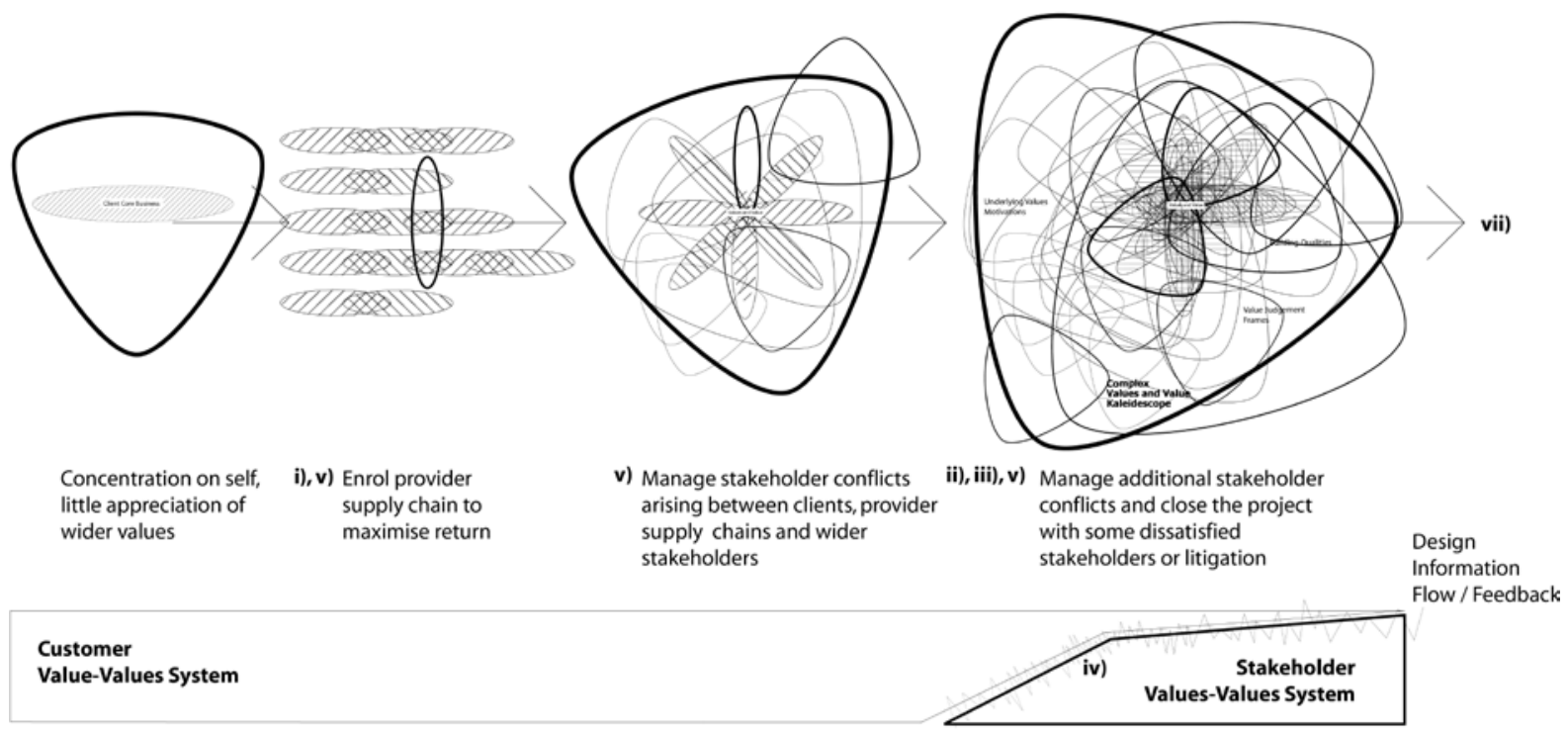

b) EMERGING CUSTOMER-SUPPLY CHAIN-STAKEHOLDER VALUE-VALUES SYSTEM - Nested / aligned within whole system

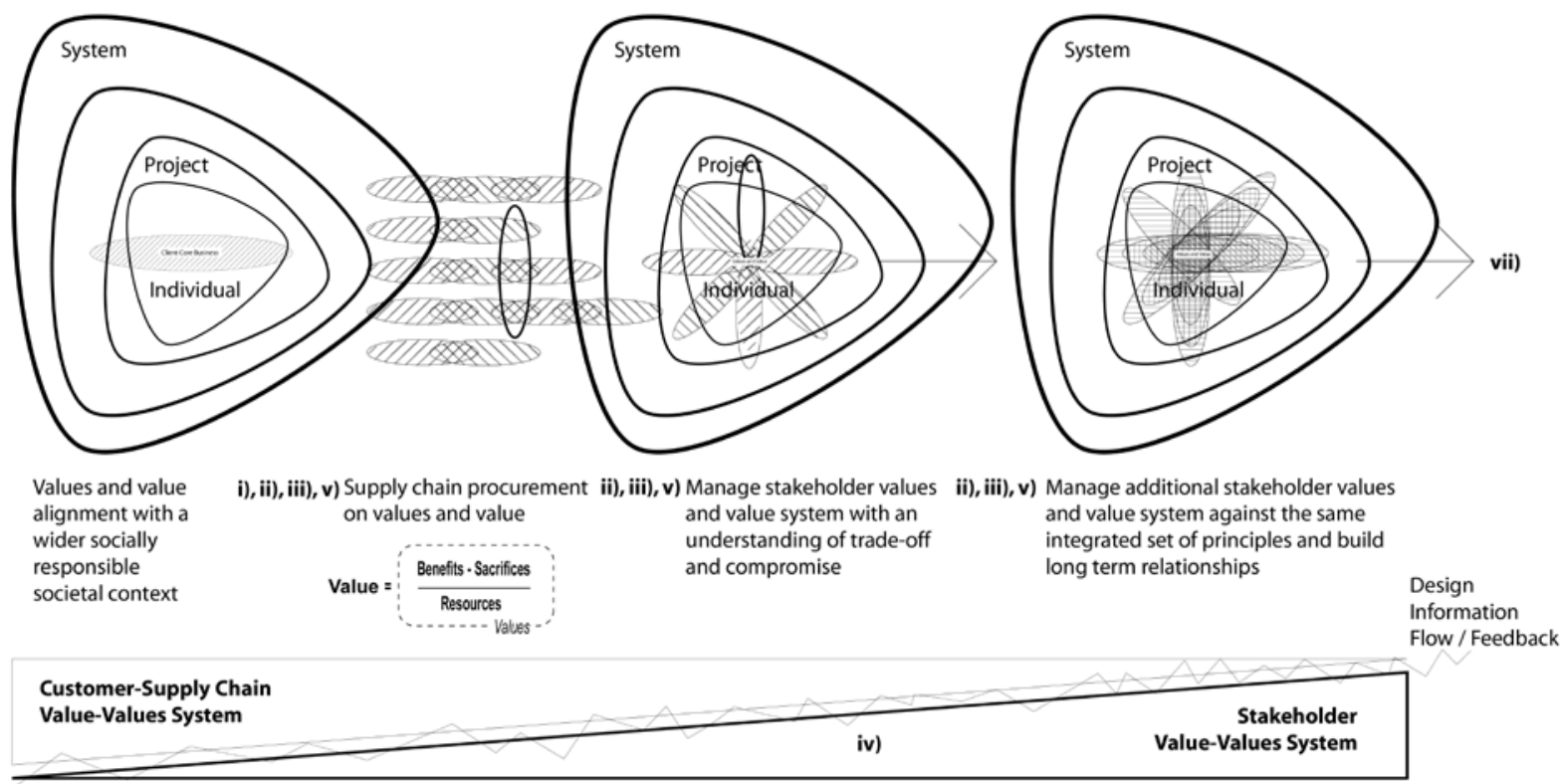

Figure 6. Two views of the emerging and adaptive

customer-supply chain-stakeholder value-values system 
Table 1 Triggered values from stakeholder value criteria during interviews

\begin{tabular}{|c|c|c|c|}
\hline Stakeholder & $\begin{array}{l}\text { Examples of Triggered Unique } \\
\text { Stakeholder Values (Verbatim) }\end{array}$ & $\begin{array}{l}\text { Associated Universal Values (Schwartz 1992, Mills et al., } \\
\text { 2009) }\end{array}$ & Temporal Nature of Values (Figure 1) \\
\hline $\begin{array}{l}\text { a. Public - Local } \\
\text { Councillor } \\
\text { (13 value criteria) }\end{array}$ & $\begin{array}{l}\text { 'green travel', 'safe routes', 'safe } \\
\text { circulation', 'stimulate learning', } \\
\text { 'work together/share', 'head } \\
\text { teacher...control', 'controlled } \\
\text { navigation' }\end{array}$ & $\begin{array}{l}\text { Universalism }>\text { PROTECTING THE ENVIRONMENT } \\
\text { Security }>\text { SECURITY OF FRIENDS AND FAMILY } \\
\text { Achievement }>\text { LEARNING } \\
\text { Others Oriented }>\text { HELPFUL } \\
\text { Power }>\text { SOCIAL POWER } \\
\text { Conformity }>\text { SELF-DISCIPLINE } \\
(n=6)\end{array}$ & $\begin{array}{l}\text { All expressions of values were experience-based, } \\
\text { ascribed to the use and operation of the asset post } \\
\text { occupancy (vii - Figure 1). }\end{array}$ \\
\hline $\begin{array}{l}\text { b. Public }- \\
\text { Regeneration } \\
\text { (13 value criteria) }\end{array}$ & $\begin{array}{l}\text { 'discourage anti-social behaviour } \\
\text { and citizenship' }\end{array}$ & $\begin{array}{l}\text { Universalism > PEACE BETWEEN PEOPLE } \\
(\mathrm{n}=1)\end{array}$ & $\begin{array}{l}\text { All expressions of values were experience-based } \\
\text { ascribed to the use and operation of the asset post } \\
\text { occupancy (vii - Figure 1). }\end{array}$ \\
\hline $\begin{array}{l}\text { c. Public - Planning } \\
\text { (14 value criteria) }\end{array}$ & $\begin{array}{l}\text { 'green travel', 'achievement', } \\
\text { 'secure by design', 'retained } \\
\text { habitats, landscaping and } \\
\text { biodiversity', 'adaptable to } \\
\text { changing teaching styles', 'retain } \\
\text { mature trees' }\end{array}$ & $\begin{array}{l}\text { Universalism > PROTECTING THE ENVIRONMENT } \\
\text { Security }>\text { SECURITY OF FRIENDS AND FAMILY } \\
\text { Universalism }>\text { UNITY WITH NATURE } \\
\text { Achievement }>\text { LEARNING } \\
(n=4)\end{array}$ & $\begin{array}{l}\text { All expressions of values were experience-based, } \\
\text { ascribed to the use and operation of the asset post } \\
\text { occupancy (vii - Figure 1), although multi- } \\
\text { stakeholder values perceptions in design decision- } \\
\text { making framed judgement on the size of the wind } \\
\text { turbine (iv and vi - Figure 1). There was one } \\
\text { comparison with existing values (iii). }\end{array}$ \\
\hline $\begin{array}{l}\text { e. School } \\
\text { Leadership } \\
\text { (19 criteria) }\end{array}$ & $\begin{array}{l}\text { 'small and nurturing', 'promote } \\
\text { belonging', 'shared facilities', } \\
\text { 'positive and calming } \\
\text { environment', 'security made fun', } \\
\text { 'encourage the community to take } \\
\text { responsibility', 'unsafe places', } \\
\text { 'creation of school community', } \\
\text { 'show awareness', 'engaging and a } \\
\text { wow', 'interesting, grounds', } \\
\text { 'attractive', 'learning', } \\
\text { 'wow to inspire the community' }\end{array}$ & $\begin{array}{l}\text { Achievement }>\text { LEARNING } \\
\text { Security }>\text { SENSE OF BELONGING } \\
\text { Others Oriented }>\text { HELPFUL } \\
\text { Hedonism }>\text { ENJOYING WORK } \\
\text { Others Oriented }>\text { RESPONSIBLE } \\
\text { Security }>\text { SECURITY OF FRIENDS AND FAMILY } \\
\text { Others Oriented > MEANING IN WORK } \\
\text { Self Direction }>\text { CURIOUS } \\
\text { Stimulating }>\text { EXCITEMENT IN WORK } \\
\text { Universalism }>\text { AESTHETIC BEAUTY } \\
\text { Achievement }>\text { INFLUENTIAL } \\
\text { Security }>\text { HEALTHY } \\
\text { Security }>\text { SECURITY OF FRIENDS AND FAMILY } \\
\text { Conformity }>\text { SELF-DISCIPLINE } \\
\text { Security }>\text { SOCIAL ORDER } \\
\text { Self Direction }>\text { CHOOSING OWN GOALS } \\
\text { Self Direction }>\text { INDEPENDENT } \\
\text { Tradition }>\text { RESPECT FOR TRADITION } \\
(n=18)\end{array}$ & $\begin{array}{l}\text { Most expressions of values were experience-based, } \\
\text { ascribed to the use and operation of the asset post } \\
\text { occupancy (vii - Figure 1). Three instances } \\
\text { ascribed values to relationships within the project } \\
\text { team (iv - Figure 1); two of these related to } \\
\text { dissatisfaction in a relationship with a third party } \\
\text { provider (ii and iii), and one expressed a positive } \\
\text { relationship with the design team (v). In four } \\
\text { instances, values were expressed when defining } \\
\text { value and reflecting on how the existing building } \\
\text { enabled or constrained values being realised (iii). }\end{array}$ \\
\hline $\begin{array}{l}\text { f. School } \\
\text { Practitioners } \\
\text { (19 value criteria) }\end{array}$ & $\begin{array}{l}\text { 'shared storage', 'swap', 'safe } \\
\text { storage', 'support', 'openness and } \\
\text { space', 'sharing', 'shared space', } \\
\text { 'attractive spaces', 'culture of } \\
\text { learning', 'calming', 'positive and } \\
\text { calming', 'consistency and } \\
\text { uniformity', 'schools creative and } \\
\text { funky curriculum', 'health', } \\
\text { 'everyone together' }\end{array}$ & $\begin{array}{l}\text { Others Oriented > HELPFUL } \\
\text { Security }>\text { SECURITY OF FRIENDS AND FAMILY } \\
\text { Achievement }>\text { LEARNING } \\
\text { Universalism }>\text { AESTHETIC BEAUTY } \\
\text { Universalism }>\text { UNITY WITH NATURE } \\
\text { Security }>\text { HEALTHY } \\
\text { Conformity }>\text { SELF-DISCIPLINE } \\
\text { Security }>\text { CLEAN } \\
\text { Tradition }>\text { RESPECT FOR TRADITION } \\
\text { Security }>\text { SENSE OF BELONGING } \\
\text { Self Direction }>\text { CREATIVITY } \\
\text { Stimulating }>\text { EXCITEMENT IN WORK } \\
\text { Universalism }>\text { BROADMINDED } \\
\text { Universalism }>\text { EQUALITY } \\
(n=14)\end{array}$ & $\begin{array}{l}\text { Most expressions of values were experience-based, } \\
\text { ascribed to the use and operation of the asset post } \\
\text { occupancy (vii - Figure 1). In six instances, values } \\
\text { were ascribed to existing buildings, either their } \\
\text { own (iii) or, in two cases, in comparison with an } \\
\text { exemplar project. }\end{array}$ \\
\hline $\begin{array}{l}\text { g. Site Management } \\
\text { (19 value criteria) }\end{array}$ & $\begin{array}{l}\text { 'learning access', 'learning } \\
\text { environment', 'minimise feelings of } \\
\text { discrimination', 'unsafe crossings', } \\
\text { 'secure foyer/reception', 'security } \\
\text { glass', 'clean and clean' }\end{array}$ & $\begin{array}{l}\text { Achievement }>\text { LEARNING } \\
\text { Universalism }>\text { EQUALITY } \\
\text { Security }>\text { SECURITY OF FRIENDS AND FAMILY } \\
\text { Security }>\text { CLEAN } \\
\text { Others Oriented }>\text { HELPFUL } \\
\text { Universalism }>\text { PROTECTING THE ENVIRONMENT } \\
(n=6)\end{array}$ & $\begin{array}{l}\text { Most expressions of values were experience-based, } \\
\text { ascribed to the use and operation of the asset post } \\
\text { occupancy (vii - Figure 1). Three instances } \\
\text { ascribed negative values impressions to the } \\
\text { existing building (iii) and one instance made } \\
\text { comparison with an exemplar project. }\end{array}$ \\
\hline $\begin{array}{l}\text { h. LEA Client } \\
\text { (17 value criteria) }\end{array}$ & $\begin{array}{l}\text { 'hub created for learning', } \\
\text { 'stakeholders work effectively } \\
\text { together', 'effective working } \\
\text { together', 'innovative spaces', } \\
\text { 'innovative,' 'learning and } \\
\text { attainment', 'the aesthetic side of } \\
\text { technologies', 'the ative } \\
\text { the quality of soft finishings', } \\
\text { 'enjoyable', 'collaboration with } \\
\text { health provision', 'learning to drive } \\
\text { sustainability' }\end{array}$ & $\begin{array}{l}\text { Achievement }>\text { LEARNING } \\
\text { Achievement }>\text { SUCCESSFUL } \\
\text { Stimulating }>\text { INNOVATION } \\
\text { Universalism }>\text { AESTHETIC BEAUTY } \\
\text { Hedonism }>\text { ENJOYING WORK } \\
\text { Others Oriented > HELPFUL } \\
\text { Security > HEALTHY } \\
\text { Universalism }>\text { PROTECTING THE ENVIRONMENT } \\
\text { Self Direction }>\text { INDEPENDENT } \\
(n=9)\end{array}$ & $\begin{array}{l}\text { Most expressions of values were experience-based, } \\
\text { ascribed to the use and operation of the asset post } \\
\text { occupancy (vii - Figure 1). Seven instances } \\
\text { ascribed values to relationships within the project } \\
\text { team (iv - Figure 1); two of these were a negative } \\
\text { relationship with a third party provider (ii and iii). }\end{array}$ \\
\hline $\begin{array}{l}\text { i. Client Delivery } \\
\text { (14 value criteria) }\end{array}$ & $\begin{array}{l}\text { 'compliance', 'fully secure', 'site } \\
\text { well integrated with buildings', } \\
\text { 'reinforces self-esteem,', 'creates a } \\
\text { hub for learning' 'inspires } \\
\text { thought, reflection, imagination } \\
\text { and enquiry', 'visionary } \\
\text { leadership', 'unhelpful split } \\
\text { between sure start and education' }\end{array}$ & $\begin{array}{l}\text { Conformity }>\text { DUTIFUL AND PROFESSIONAL } \\
\text { Security }>\text { SECURITY OF FRIENDS AND FAMILY } \\
\text { Universalism > UNITY WITH NATURE } \\
\text { Self Direction }>\text { SELF-RESPECT } \\
\text { Achievement }>\text { LEARNING } \\
\text { Self Direction }>\text { CREATIVITY } \\
\text { Achievement }>\text { INTELLIGENT } \\
\text { Achievement }>\text { AMBITIOUS } \\
\text { Achievement }>\text { INFLUENTIAL } \\
\text { Others Oriented }>\text { HELPFUL } \\
\text { Self Direction }>\text { CHOOSING OWN GOALS } \\
\text { Power }>\text { AUTHORITY } \\
(n=12)\end{array}$ & $\begin{array}{l}\text { Most expressions of values were experience-based, } \\
\text { ascribed to the use and operation of the asset post } \\
\text { occupancy (vii - Figure 1). Three instances } \\
\text { ascribed values to relationships within the project } \\
\text { team (iv - Figure 1); one of these was a negative } \\
\text { relationship with a third party provider (ii and iii). }\end{array}$ \\
\hline $\begin{array}{l}\text { j. Design Advisory } \\
\text { Group } \\
\text { (20 value criteria) }\end{array}$ & $\begin{array}{l}\text { 'shared staff facilities', 'sharing } \\
\text { rooms', 'significant innovation', } \\
\text { 'collaboration', 'integration', } \\
\text { 'sustainability of sure start', 'green } \\
\text { travel plan', 'cluttered with mats', } \\
\text { 'hub for learning', 'sustainability } \\
\text { must provide a learning } \\
\text { opportunity' }\end{array}$ & $\begin{array}{l}\text { Others Oriented }>\text { HELPFUL } \\
\text { Stimulating }>\text { INNOVATION } \\
\text { Universalism }>\text { PROTECTING THE ENVIRONMENT } \\
\text { Achievement }>\text { LEARNING } \\
\text { Universalism }>\text { AESTHETIC BEAUTY } \\
\text { Security }>\text { HEALTHY } \\
\text { Security }>\text { SECURITY OF FRIENDS AND FAMILY } \\
(n=7)\end{array}$ & $\begin{array}{l}\text { Most expressions of values were experience-based, } \\
\text { ascribed to the use and operation of the asset post } \\
\text { occupancy (vii - Figure 1). Four instances ascribed } \\
\text { values to buildings (iv - Figure 1); three of these } \\
\text { were negative (one ascribed to an exemplar and } \\
\text { two to the future building design). }\end{array}$ \\
\hline
\end{tabular}




\begin{tabular}{|c|c|c|c|}
\hline $\begin{array}{l}\text { k. Design Team } \\
\text { (15 value criteria) }\end{array}$ & $\begin{array}{l}\text { 'stakeholders working together', } \\
\text { 'promotes the integration of the } \\
\text { public', 'sustainable life and } \\
\text { structure', 'future communities', } \\
\text { 'little freedom', 'sustainable } \\
\text { features,', 'sustainability is down to } \\
\text { the client' }\end{array}$ & $\begin{array}{l}\text { Others Oriented }>\text { HELPFUL } \\
\text { Security }>\text { SENSE OF BELONGING } \\
\text { Universalism }>\text { PROTECTING THE ENVIRONMENT } \\
\text { Self Direction }>\text { FREEDOM } \\
\text { Achievement }>\text { CAPABLE } \\
\text { Achievement }>\text { SUCCESSFUL } \\
(n=6)\end{array}$ & $\begin{array}{l}\text { Most expressions of values were experience-based, } \\
\text { ascribed to the use and operation of the asset post } \\
\text { occupancy (vii - Figure 1). Three instances related } \\
\text { to the relationship with the project (iv - Figure 1): } \\
\text { one involved a client relationship, one the } \\
\text { avoidance of negative impressions and one the } \\
\text { positive interactions of the team. }\end{array}$ \\
\hline $\begin{array}{l}\text { l. Sustainability } \\
\text { Advisory Group } \\
\text { (17 value criteria) }\end{array}$ & $\begin{array}{l}\text { Direct }(n=1)-\text { 'green travel plan', } \\
\text { Indirect }(n=1)-\text { 'more efficient } \\
\text { and cheaper to install' }\end{array}$ & $\begin{array}{l}\text { Universalism > PROTECTING THE ENVIRONMENT } \\
\text { Achievement }>\text { SUCCESSFUL } \\
\text { Achievement }>\text { CAPABLE } \\
(n=3)\end{array}$ & $\begin{array}{l}\text { One expression was of planned values (vii - Figure } \\
\text { 1) and one ascribed to the asset exchange (vi). }\end{array}$ \\
\hline $\begin{array}{ll}\text { Total 180 } & \text { Value } \\
\text { Criteria }\end{array}$ & & Overall Total: 86 Associated Universal Values & \\
\hline
\end{tabular}


Table2. Value Criteria Triggering Subjective Stakeholder Expressions related to Values
$\mathbf{1 4}$

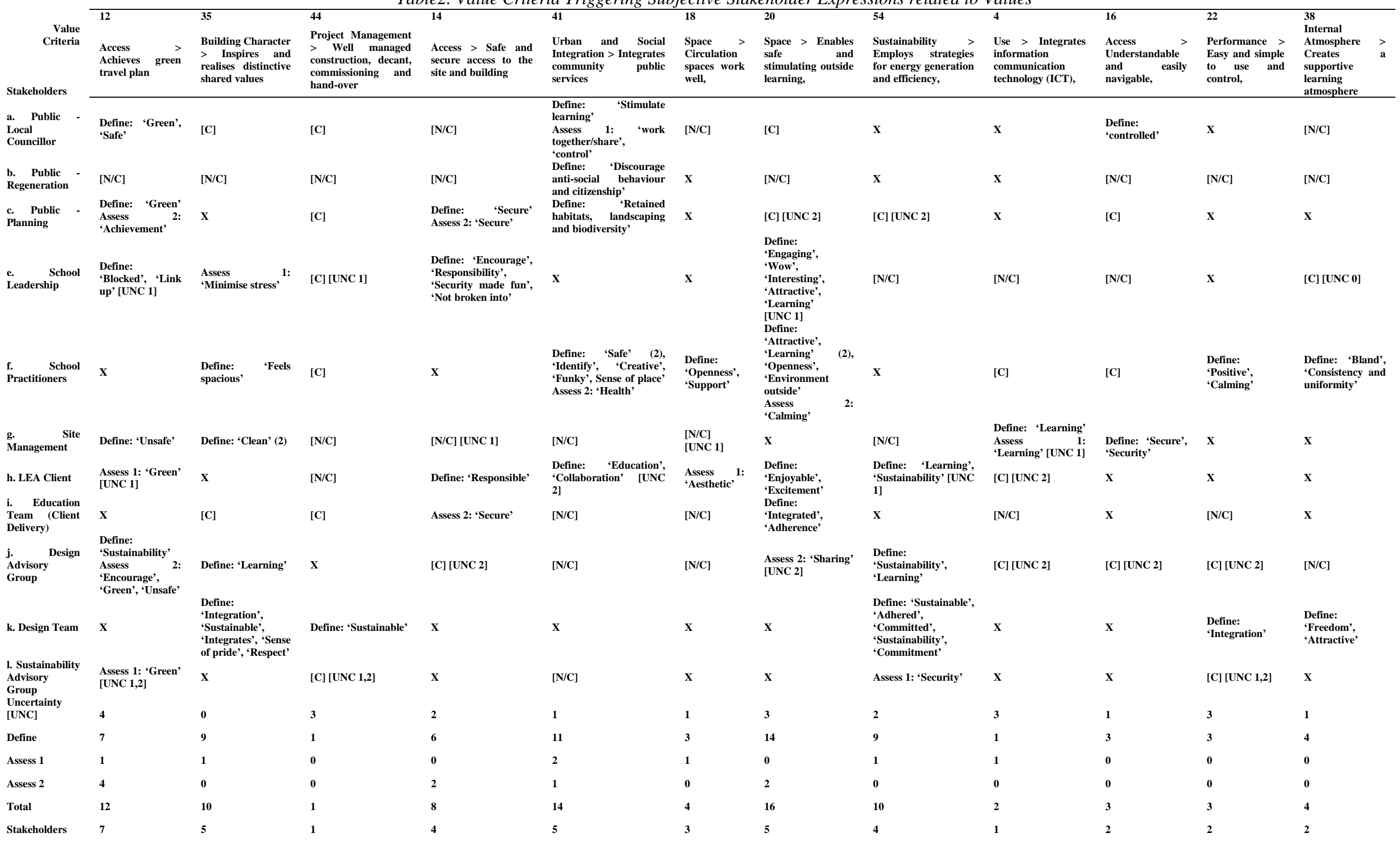


Table 2 (continued). Value Criteria Triggering Subjective Stakeholder Expressions related to Values

\begin{tabular}{|c|c|c|c|c|c|c|c|c|c|c|c|c|c|c|c|c|c|}
\hline \multirow{4}{*}{$\begin{array}{l}\text { a. Public - Local } \\
\text { Councillor } \\
\text { b. Public - } \\
\text { Regeneration }\end{array}$} & \multirow[b]{2}{*}{$\begin{array}{l}9 \\
9 \\
\text { Use > Enhances } \\
\text { teaching and } \\
\text { learning, }\end{array}$} & \multirow[b]{2}{*}{$\begin{array}{l}17 \\
\text { Space }>\text { Adequate } \\
\text { and appropiate } \\
\text { range of physical } \\
\text { and electronic } \\
\text { storage, }\end{array}$} & \multirow[b]{2}{*}{$\begin{array}{l}23 \\
\text { Performance > } \\
\text { Responds to the } \\
\text { site, }\end{array}$} & \multirow[b]{2}{*}{$\begin{array}{l}42 \\
\text { Urban and Social } \\
\text { Integration > } \\
\text { Provides a suitable } \\
\text { level of } \\
\text { prominence, visual } \\
\text { integration and } \\
\text { sense of place }\end{array}$} & \multirow[b]{2}{*}{$\begin{array}{l}46 \\
\text { Project } \\
\text { Management > } \\
\text { The client brief is } \\
\text { inspiring, concise } \\
\text { and all funding } \\
\text { arrangements are } \\
\text { clear }\end{array}$} & \multirow[b]{2}{*}{$\begin{array}{l}1 \\
\text { Use }>\text { Meets } \\
\text { space } \\
\text { requirements of } \\
\text { users, }\end{array}$} & \multirow[b]{2}{*}{$\begin{array}{l}2 \\
\text { Use } \\
\text { Delivers } \\
\text { needed } \\
\text { adaptabilit } \\
\text { y, }\end{array}$} & \multirow[b]{2}{*}{$\begin{array}{l}8 \\
\text { Use } \\
\text { Furniture is } \\
\text { multi- } \\
\text { functional, } \\
\text { robust and } \\
\text { designed to } \\
\text { suit all users, } \\
\end{array}$} & \multirow[b]{2}{*}{$\begin{array}{l}3 \\
\text { Project } \\
\text { Management > > } \\
\text { Effective project } \\
\text { team integration } \\
\text { and design } \\
\text { management, }\end{array}$} & \multirow[b]{2}{*}{$\begin{array}{l}55 \\
\text { Sustainability } \\
>\text { Delivers a } \\
\text { green waste } \\
\text { management } \\
\text { strategy, }\end{array}$} & \multirow[b]{2}{*}{$\begin{array}{l}3 \\
\text { Use } \\
\text { Delivers } \\
\text { needed space } \\
\text { flexibility, }\end{array}$} & \multirow[b]{2}{*}{$\begin{array}{l}32 \\
\text { Construction > } \\
\text { Provides high } \\
\text { quality, } \\
\text { coordinated } \\
\text { fixtures, fittings, } \\
\text { finishes and } \\
\text { appliances } \\
\end{array}$} & \multirow{2}{*}{\multicolumn{2}{|c|}{ 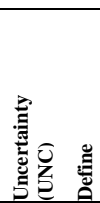 }} & \multirow[b]{2}{*}{$\begin{array}{l}\overline{5} \\
\text { 惫 } \\
\end{array}$} & \multirow{2}{*}{\multicolumn{2}{|c|}{ 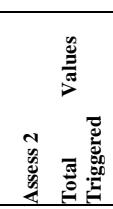 }} \\
\hline & & & & & & & & & & & & & & & & & \\
\hline & $\mathrm{x}$ & $\mathrm{x}$ & {$[\mathrm{C}]$} & {$[\mathrm{N} / \mathrm{C}]$} & {$[\mathrm{N} / \mathrm{C}]$} & $\mathrm{x}$ & $\mathrm{x}$ & {$[\mathrm{N} / \mathrm{C}]$} & $\mathrm{x}$ & $\mathrm{x}$ & $\mathrm{x}$ & $\mathrm{x}$ & 0 & 4 & 2 & 0 & 6 \\
\hline & {$[\mathrm{N} / \mathrm{C}]$} & $\mathrm{x}$ & {$[\mathrm{N} / \mathrm{C}]$} & {$[\mathrm{N} / \mathrm{C}]$} & {$[\mathrm{N} / \mathrm{C}]$} & $\mathrm{x}$ & $\begin{array}{l}\mathrm{X} \\
\text { Define: }\end{array}$ & {$[\mathrm{N} / \mathrm{C}]$} & $\mathrm{x}$ & $\mathrm{x}$ & $\mathrm{x}$ & $\mathrm{x}$ & $\mathbf{0}$ & 1 & 0 & 0 & 0 \\
\hline c. Public - Planning & $\mathrm{x}$ & $\mathrm{x}$ & $\begin{array}{l}\text { Define: } \\
\text { ‘Attractive' }\end{array}$ & {$[\mathrm{N} / \mathrm{C}]$} & {$[\mathrm{N} / \mathrm{C}]$} & [C] & $\begin{array}{l}\text { 'Learning } \\
\text { platform' } \\
\text { [UNC 2] }\end{array}$ & {$[\mathrm{N} / \mathrm{C}]$} & $\mathrm{x}$ & $\begin{array}{l}\text { Define: } \\
\text { 'Learning' }\end{array}$ & Des & $\mathrm{x}$ & 3 & 6 & 0 & 2 & 8 \\
\hline $\begin{array}{l}\text { e. } \\
\text { Leadership School }\end{array}$ & $\begin{array}{l}\text { Define: } \\
\text { 'Positive', } \\
\text { 'Calming' }\end{array}$ & $\begin{array}{l}\text { Define: 'Choice', } \\
\text { 'Freely' }\end{array}$ & $\mathrm{x}$ & $\mathrm{x}$ & $\mathrm{x}$ & $\mathrm{x}$ & $\mathrm{x}$ & $\begin{array}{l}\text { Define: } \\
\text { 'Shared' }\end{array}$ & $\mathrm{x}$ & $\mathrm{x}$ & $\begin{array}{l}\text { Define: } \\
\text { 'Nurturing', } \\
\text { 'Belonging' } \\
\text { (2) }\end{array}$ & $\mathrm{x}$ & 4 & 19 & 1 & 0 & 20 \\
\hline $\begin{array}{l}\text { f. School } \\
\text { Practitioners }\end{array}$ & [C] & Assess 2: 'Shared’ & $\mathrm{x}$ & $\mathrm{x}$ & $\mathrm{x}$ & $\begin{array}{l}\text { Define: 'Share' } \\
\text { (2), 'Exchange' } \\
\text { (2) } \\
\text { Assess , 2: } \\
\text { 'Share', } \\
\text { 'Exchange' }\end{array}$ & $\mathrm{x}$ & $\begin{array}{l}\text { Define: } \\
\text { 'Shared, } \\
\text { 'Sharing', }\end{array}$ & $\mathrm{x}$ & $\mathrm{x}$ & $\begin{array}{l}\text { Define: } \\
\text { 'Swap', } \\
\text { 'Sharing' } \\
\text { [UNC 2] }\end{array}$ & $\mathrm{x}$ & 1 & 26 & 0 & 5 & 31 \\
\hline g. Site Management & $\begin{array}{l}\text { X } \\
\text { Define: } \\
\text { 'Inovative', } \\
\text { 'Attainment' }\end{array}$ & {$[\mathrm{N} / \mathrm{C}]$} & {$[\mathrm{N} / \mathrm{C}]$} & $\mathrm{x}$ & $\mathrm{x}$ & $\begin{array}{l}\text { X } \\
\text { Define: } \\
\text { 'Learning', } \\
\text { 'Work- }\end{array}$ & $\mathrm{x}$ & $\mathrm{x}$ & $\mathrm{x}$ & {$[\mathrm{C}]$} & $\mathrm{x}$ & $\mathrm{x}$ & 3 & 6 & 1 & 0 & 7 \\
\hline h. LEA Client & $\begin{array}{l}\text { Atanment } \\
\text { Assess } \\
\text { 'Inovative', } \\
\text { 'Attainment' } \\
\text { [UNC 0,1,2] }\end{array}$ & $\mathrm{x}$ & $\mathrm{x}$ & $\mathrm{x}$ & $\mathrm{x}$ & $\begin{array}{l}\text { effectively } \\
\text { together' } \\
\text { Assess } \quad 2: \\
\text { 'Shared', } \\
\text { 'Innovative' }\end{array}$ & {$[\mathrm{C}]$} & {$[\mathrm{C}]$} & [C] [UNC 2] & {$[\mathrm{N} / \mathrm{C}]$} & $\mathrm{x}$ & $\mathrm{x}$ & 8 & 11 & 4 & 2 & 17 \\
\hline $\begin{array}{l}\text { i. Education Team } \\
\text { (Client Delivery) }\end{array}$ & {$[\mathrm{N} / \mathrm{C}]$} & $\mathrm{x}$ & $\mathrm{x}$ & $\begin{array}{l}\text { Define: } \\
\text { 'Adherence' }\end{array}$ & 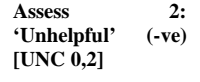 & $\mathrm{x}$ & $\mathrm{x}$ & $\mathrm{x}$ & $\begin{array}{l}\text { Define: 'Comply', } \\
\text { 'Compromised' }\end{array}$ & $\mathrm{x}$ & $\mathrm{x}$ & $\mathrm{x}$ & 2 & 5 & 0 & 2 & 7 \\
\hline $\begin{array}{l}\text { j. Design Advisory } \\
\text { Group }\end{array}$ & $\begin{array}{l}\text { 'Infine: } \\
\text { 'Innovation' } \\
\text { Assess } \\
\text { 'Collaborative', } \\
\text { 'Integration'” }\end{array}$ & $\begin{array}{l}\text { Assess 2: } \\
\text { 'Compromises' } \\
\text { [UNC 2] }\end{array}$ & $\mathrm{x}$ & $\mathrm{x}$ & $\mathrm{x}$ & $\begin{array}{l}\text { Define: } \\
\text { 'Shared', 'One } \\
\text { culture' }\end{array}$ & $\mathrm{x}$ & $\mathrm{x}$ & $\mathrm{x}$ & $\mathrm{x}$ & $\begin{array}{l}\text { Assess, 2: } \\
\text { 'Sharing', } \\
\text { 'Health'' }\end{array}$ & [C] [UNC 2] & 7 & 7 & 0 & 9 & 16 \\
\hline k. Design Team & onch & $\mathrm{x}$ & {$[\mathrm{N} / \mathrm{C}]$} & $\mathrm{x}$ & {$[\mathrm{N} / \mathrm{C}]$} & $\mathrm{x}$ & $\mathrm{x}$ & {$[\mathrm{N} / \mathrm{C}]$} & {$[\mathrm{N} / \mathrm{C}]$} & $\mathrm{x}$ & $\mathrm{x}$ & $\begin{array}{l}\text { Define: } \\
\text { 'Working } \\
\text { together' [UNC } \\
\text { 0] }\end{array}$ & 1 & 15 & 0 & 0 & 15 \\
\hline $\begin{array}{l}\text { l. Sustainability } \\
\text { Advisory Group }\end{array}$ & $\mathrm{x}$ & $\mathrm{x}$ & $\mathrm{x}$ & $\mathrm{x}$ & $\mathrm{x}$ & $\mathrm{x}$ & $\begin{array}{l}\text { Define: } \\
\text { 'Sustainab } \\
\text { le' }\end{array}$ & $\mathrm{x}$ & [C] [UNC 1] & {$[\mathrm{C}]$} & $\mathrm{x}$ & $\sqrt{3}+x_{1}$ & 7 & 1 & 2 & 0 & 3 \\
\hline Uncertainty [UNC] & 3 & 1 & 0 & 0 & 2 & 0 & 1 & 0 & 2 & 0 & 1 & 1 & & & & & \\
\hline Define 0 & 5 & 2 & 1 & 1 & 0 & 8 & 2 & 3 & 2 & 1 & 5 & 1 & & & & & \\
\hline Assess 1 & 2 & 0 & 0 & 0 & 0 & 0 & 0 & 0 & 0 & 0 & 0 & 0 & $\stackrel{m}{\circ}$ & $\bar{\Xi}$ & \& & సิ & $\stackrel{9}{-9}$ \\
\hline Assess 2 & 2 & 2 & 0 & 0 & 1 & 4 & 0 & 0 & 0 & 0 & 2 & 0 & & & & & \\
\hline Total & 9 & 4 & 1 & 1 & 1 & 12 & 2 & 3 & 2 & 1 & 7 & 1 & & & & & \\
\hline Stakeholders & 3 & 3 & 1 & 1 & 1 & 3 & 2 & 2 & 1 & 1 & 3 & 1 & & & & & \\
\hline
\end{tabular}

Key: [N/C] No Comment, [C] Comment, [UNC] Uncertainty / Information Request by stage, ' $\quad$ X' Unselected, * Difficult to categorise 
Table3. Mapping of expressions of values triggered by Value Criteria to Schwartz' Motivational Types

\begin{tabular}{|c|c|c|c|c|c|c|c|c|c|c|c|c|c|}
\hline & & 12 & 35 & 44 & 14 & 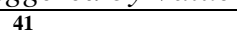 & 18 & 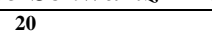 & & 4 & 16 & 22 & \\
\hline $\begin{array}{l}\text { Motivational } \\
\text { Type }\end{array}$ & Goal & $\begin{array}{l}\text { Access > Achieves } \\
\text { green travel plan }\end{array}$ & $\begin{array}{l}\text { Building Character > } \\
\text { Inspires and realises } \\
\text { distinctive shared } \\
\text { values }\end{array}$ & $\begin{array}{l}\text { Project Management } \\
>\text { Well managed } \\
\text { construction, decant, } \\
\text { commissioning and } \\
\text { hand-over }\end{array}$ & $\begin{array}{l}\text { Access > Safe and } \\
\text { secure access to } \\
\text { the site and } \\
\text { building }\end{array}$ & $\begin{array}{l}\text { Urban and Social } \\
\text { Integration } \\
\text { Integrates community } \\
\text { public services }\end{array}$ & $\begin{array}{l}\text { Space > } \\
\text { Circulati } \\
\text { on spaces } \\
\text { work } \\
\text { well }\end{array}$ & $\begin{array}{l}\text { Space > Enables } \\
\text { safe and stimulating } \\
\text { outside learning }\end{array}$ & $\begin{array}{l}\text { Sustainability > } \\
\text { Employs } \\
\text { strategies for } \\
\text { energy } \\
\text { generation and } \\
\text { efficiency }\end{array}$ & $\begin{array}{l}\text { Use > Integrates } \\
\text { information } \\
\text { communication } \\
\text { technology (ICT) }\end{array}$ & $\begin{array}{l}\text { Access > } \\
\text { Understand } \\
\text { able and } \\
\text { easily } \\
\text { navigable }\end{array}$ & $\begin{array}{l}\text { Performance > } \\
\text { Easy and } \\
\text { simple to use } \\
\text { and control }\end{array}$ & $\begin{array}{l}\text { Internal } \\
\text { Atmosphere > } \\
\text { Creates a } \\
\text { supportive } \\
\text { learning } \\
\text { atmosphere }\end{array}$ \\
\hline Universalism & $\begin{array}{l}\text { Welfare of all } \\
\text { people } \\
\text { (understanding, } \\
\text { tolerance) }\end{array}$ & $\begin{array}{l}\text { Define: 'Green' } \\
\text { (a,c), } \\
\text { 'Sustainability' (j) } \\
\text { Assess 1: 'Green' } \\
\text { (h,i) } \\
\text { Assess 2: ‘Green'(j) }\end{array}$ & $\begin{array}{l}\text { Define: 'Sustainable' } \\
\text { (k) }\end{array}$ & $\begin{array}{l}\text { Define: 'Sustainable' } \\
\text { (k) }\end{array}$ & $\begin{array}{l}\text { Define: } \\
\text { 'Responsibility' *' } \\
\text { (e) 'Responsible' } \\
\text { "(h) }\end{array}$ & $\begin{array}{l}\text { Define: rRetained } \\
\text { habitats, landscaping } \\
\text { and biodiversity' (c) }\end{array}$ & $\begin{array}{l}\text { Assess 1: } \\
\text { 'Aestheti } \\
c^{\prime} * \text { (h) }\end{array}$ & $\begin{array}{l}\text { Define: } \\
\text { 'Environment } \\
\text { outside' (f) }\end{array}$ & $\begin{array}{l}\text { Define: } \\
\text { 'Sustainability' } \\
\text { (h,I,k) } \\
\text { 'Sustainable' } \\
\text { (k) }\end{array}$ & & & & $\begin{array}{l}\text { Define: } \\
\text { 'Attractive' * } \\
\text { (k) }\end{array}$ \\
\hline 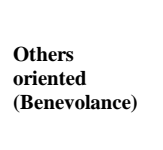 & $\begin{array}{l}\text { Welfare of } \\
\text { personal contacts }\end{array}$ & Define: ‘Link up’ (e) & $\begin{array}{l}\text { Define: 'Integration' } \\
* \text { (k) 'Integrates' * } \\
\text { (k) }\end{array}$ & & & $\begin{array}{l}\text { Define: 'Discourage } \\
\text { anti-social behaviour } \\
\text { and citizenship', (b) } \\
\text { 'Collaboration' (h) } \\
\text { Assess 1: 'work } \\
\text { together/share' (a) }\end{array}$ & $\begin{array}{l}\text { Define: } \\
\text { 'Opennes } \\
\text { s' (f) } \\
\text { 'Support } \\
\text { 'S(f) }\end{array}$ & $\begin{array}{l}\text { Define: 'Openness' ' } \\
\text { (f) 'Integrated' * (i), } \\
\text { Assess 2: 'Sharing' } \\
\text { (j) }\end{array}$ & & & & $\begin{array}{l}\text { Define: } \\
\text { 'Integration' } \\
\text { (k) }\end{array}$ & \\
\hline Tradition & $\begin{array}{l}\text { Respect, } \\
\text { commitment } \\
\text { acceptance } \\
\text { customs }\end{array}$ & & & & & & & & & & & & \\
\hline Conformity & $\begin{array}{l}\text { Avoiding upset or } \\
\text { harm to others }\end{array}$ & & & & & & & $\begin{array}{l}\text { Define: 'Adherence' } \\
\text { (i) }\end{array}$ & $\begin{array}{l}\text { Define: } \\
\text { 'Adhered', *, } \\
\text { 'Committed,', } \\
\text { 'Commitment' } \\
\text { (k) }\end{array}$ & & & & $\begin{array}{l}\text { Define: } \\
\text { 'Consistency } \\
\text { and } \\
\text { uniformity' (f) }\end{array}$ \\
\hline Security & $\begin{array}{l}\text { Safety, harmony } \\
\text { and stability }\end{array}$ & $\begin{array}{l}\text { Define: 'Unsafe' (g) } \\
\text { 'Safe' (a) } \\
\text { Assess 2: 'Unsafe' } \\
\text { (j) }\end{array}$ & $\begin{array}{l}\text { Define: } \\
\text { ‘Clean' (g) }\end{array}$ & & $\begin{array}{l}\text { Define: 'Secure' } \\
\text { (c) } \\
\text { 'Securde f fun' (e), } \\
\text { 'Not broken into' } \\
\text { (e) } \\
\text { Assess 2: 'Secure' } \\
\text { (c,i) }\end{array}$ & $\begin{array}{l}\text { Define: ‘Safe' (f,f) } \\
\text { Assess 2: 'Health' (f) }\end{array}$ & & & $\begin{array}{l}\text { 'Sssess } \\
\text { 'Security' (I) }\end{array}$ & & $\begin{array}{l}\text { Define: } \\
\text { 'Secure' (g) } \\
\text { 'Security' } \\
\text { (g) }\end{array}$ & & \\
\hline Power & $\begin{array}{l}\text { Status, prestige } \\
\text { and control }\end{array}$ & $\begin{array}{l}\text { Define: 'Blocked' } \\
\text { (e) }\end{array}$ & $\begin{array}{l}\text { Define: ‘Sense of } \\
\text { pride' * (k) 'Respect' } \\
* \text { *(k) }\end{array}$ & & & Assess 1: 'Control’ (a) & & & & & $\begin{array}{l}\text { Define: } \\
\text { 'Controlled' } \\
\text { (a) }\end{array}$ & & \\
\hline Achievement & $\begin{array}{l}\text { Personal success } \\
\text { and competence }\end{array}$ & 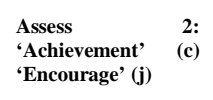 & Define: ‘Learning’ (j) & & $\begin{array}{l}\text { Define: } \\
\text { 'Encourage' (e) }\end{array}$ & $\begin{array}{lr}\text { Define: } & \text { 'Stimulate } \\
\text { learning' } & \text { (a) } \\
\text { 'Education' } & \text { (g) }\end{array}$ & & $\begin{array}{l}\text { Define: 'Learning' } \\
\text { (e,f,f) }\end{array}$ & $\begin{array}{l}\text { Define: } \\
\text { 'Learning' }(h, j)\end{array}$ & 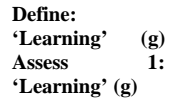 & & $\begin{array}{l}\text { Define: } \\
\text { 'Positive' * (f) }\end{array}$ & \\
\hline $\begin{array}{l}\text { Hedonism } \\
\text { (Enjoyment) }\end{array}$ & $\begin{array}{l}\text { Pleasure } \\
\text { sensuous } \\
\text { gratification }\end{array}$ & & 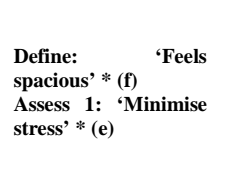 & & & $\begin{array}{l}\text { Define: 'Identify' * (f), } \\
\text { Sense of place' * (f) }\end{array}$ & & 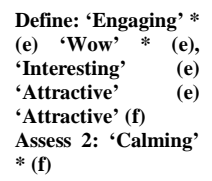 & & & & $\begin{array}{l}\text { Define: } \\
\text { 'Calming' * (f) }\end{array}$ & $\begin{array}{l}\text { Define: } \\
\text { 'Bland' * (f) }\end{array}$ \\
\hline Stimulation & $\begin{array}{l}\text { Excitement, } \\
\text { novelty } \\
\text { challenge }\end{array}$ & & & & & & & $\begin{array}{l}\text { Define: 'Enjoyable' } \\
\text { (h) 'Excitement' (h) }\end{array}$ & & & & & $\begin{array}{l}\text { Define: } \\
\text { 'Freedom' (k) }\end{array}$ \\
\hline Self-direction & $\begin{array}{l}\text { Independent } \\
\text { thought and action }\end{array}$ & & & & & $\begin{array}{l}\text { Define: } \\
\text { 'Funky' (f) }\end{array}$ & & & & & & & \\
\hline Define & & 7 & 9 & 1 & 6 & 11 & 3 & 14 & 9 & 1 & 3 & 3 & 4 \\
\hline Assess 1 & & 1 & 1 & 0 & 0 & 2 & 1 & 0 & 1 & 1 & $\mathbf{0}$ & 0 & $\mathbf{0}$ \\
\hline Assess 2 & & 4 & $\mathbf{0}$ & 0 & 2 & 1 & 0 & 2 & 0 & 0 & 0 & 0 & 0 \\
\hline Total & & 12 & 10 & 1 & 8 & 14 & 4 & 16 & 10 & 2 & 3 & 3 & 4 \\
\hline
\end{tabular}

KEY - ‘*’' Difficult to assign to any one values category, for example 'reducing stress' is not strictly an end in itself because it could be delivered to achieve 'safety', 'achievement' or 'hedonism’ universal values goals. 
Table 3 (continued). Mapping of expressions of values triggered by Value Criteria to Schwartz’ Motivational Types
17

\begin{tabular}{|c|c|c|c|c|c|c|c|c|c|c|c|c|c|c|c|c|c|}
\hline & & & & & & & & & & & & & & & & & \\
\hline $\begin{array}{l}\text { Motivational } \\
\text { Type }\end{array}$ & Goal & $\begin{array}{l}\text { Use > Enhances } \\
\text { teaching and } \\
\text { learning }\end{array}$ & $\begin{array}{l}17 \\
\text { Space > } \\
\text { Adequate and } \\
\text { appropriate } \\
\text { range of } \\
\text { physical and } \\
\text { electronic } \\
\text { storage }\end{array}$ & $\begin{array}{l}\text { Performanc } \\
\text { e > } \\
\text { Responds to } \\
\text { the site }\end{array}$ & $\begin{array}{l}42 \\
\text { Urban and Social } \\
\text { Integration }> \\
\text { Provides a suitable } \\
\text { level of prominence, } \\
\text { visual integration } \\
\text { and sense of place }\end{array}$ & $\begin{array}{l}46 \\
\text { Project } \\
\text { Managemen } \\
t \quad>\text { The } \\
\text { client brief } \\
\text { is inspiring, } \\
\text { concise and } \\
\text { all funding } \\
\text { arrangemen } \\
\text { ts are clear }\end{array}$ & $\begin{array}{l}1 \\
\text { Use > Meets } \\
\text { space } \\
\text { requirements of } \\
\text { users }\end{array}$ & $\begin{array}{l}2 \\
\text { Use } \\
\text { Delivers } \\
\text { needed } \\
\text { adaptability }\end{array}$ & $\begin{array}{l}8 \\
\text { Use } \\
\text { Furniture is } \\
\text { multi- } \\
\text { functional, } \\
\text { robust and } \\
\begin{array}{l}\text { designed to } \\
\text { suit all users }\end{array}\end{array}$ & $\begin{array}{l}33 \\
\text { Project } \\
\text { Management > } \\
\text { Effective } \\
\text { project team } \\
\text { integration } \\
\text { and design } \\
\text { management }\end{array}$ & 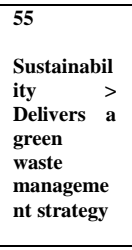 & $\begin{array}{l}\text { Use }>\text { Delivers } \\
\text { needed space } \\
\text { flexibility }\end{array}$ & $\begin{array}{l}32 \\
\text { Construction > } \\
\text { Provides high } \\
\text { quality, } \\
\text { coordinated } \\
\text { fixtures, } \\
\text { fittings, } \\
\text { finishes and } \\
\text { appliances }\end{array}$ & 苞 & 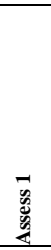 & 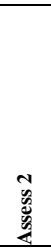 & 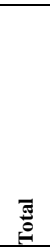 \\
\hline Universalism & $\begin{array}{l}\text { Welfare of all } \\
\text { people } \\
\text { (understanding, } \\
\text { tolerance) }\end{array}$ & & & $\begin{array}{l}\text { Define: } \\
\text { 'Attractive' } \\
\text { * (c) }\end{array}$ & & & & $\begin{array}{l}\text { Define: } \\
\text { 'Sustainable } \\
\text { '(l) }\end{array}$ & & & & & & 16 & 3 & 1 & 21 \\
\hline $\begin{array}{l}\text { Others } \\
\text { oriented } \\
\text { (Benevolance) }\end{array}$ & $\begin{array}{l}\text { Welfare of } \\
\text { personal contacts }\end{array}$ & $\begin{array}{l}\text { Assess } \\
\text { 'Collaborative' } \\
\text { (j), 'Integration' } \\
\text { (j) }\end{array}$ & $\begin{array}{l}\text { Assess }{ }^{2:} \quad 2: \\
\text { 'Shared' (f) } \\
\text { 'Compromises } \\
{ }^{*}(\mathrm{j})\end{array}$ & & & $\begin{array}{l}\text { Assess 2: } \\
\text { 'Unhelpful' } \\
\text { (-ve) (i) }\end{array}$ & $\begin{array}{l}\text { Define: 'Share', } \\
\text { (f,f) 'Exchange' } \\
\text { (f,f) 'Shared' (j) } \\
\text { 'One culture' (j) } \\
\text { Assess 2: 'Share' } \\
\text { (f) 'Exchange' (f) } \\
\text { 'Shared' (h) }\end{array}$ & & $\begin{array}{l}\text { Define: } \\
\text { 'Shared' (e,f) } \\
\text { 'Sharing' (f) }\end{array}$ & $\begin{array}{l}\text { Define: } \\
\text { 'Compromised } \\
\text { "* (i) }\end{array}$ & & $\begin{array}{l}\text { Define: } \\
\text { 'Nurturing' * * } \\
\text { (e), } \\
\text { 'Belonging' } \\
\text { (e,e) } \\
\text { 'Swap' (f), } \\
\text { 'Sharing' (f) } \\
\text { Assess 2: } \\
\text { 'Sharing' (j) }\end{array}$ & $\begin{array}{l}\text { Define: } \\
\text { 'Working } \\
\text { together' (k) }\end{array}$ & 26 & 1 & 10 & 37 \\
\hline Tradition & $\begin{array}{l}\text { Respect, } \\
\text { commitment and } \\
\text { acceptance of } \\
\text { customs }\end{array}$ & & & & & & & & & & & & & 0 & 0 & 0 & 0 \\
\hline Conformity & $\begin{array}{l}\text { Avoiding upset or } \\
\text { harm to others }\end{array}$ & & & & $\begin{array}{l}\text { Define: ‘Adherence’ } \\
\text { (i) }\end{array}$ & & & & & $\begin{array}{l}\text { Define: } \\
\text { 'Comply' (i) }\end{array}$ & & & & 7 & 0 & 0 & 7 \\
\hline Security & $\begin{array}{l}\text { Safety, harmony } \\
\text { and stability }\end{array}$ & & & & & & & & & & & $\begin{array}{l}\text { Assess } \\
\text { 'Health' (j) }\end{array}$ & & 11 & 1 & 5 & 17 \\
\hline Power & $\begin{array}{l}\text { Status, prestige } \\
\text { and control }\end{array}$ & & & & & & & & & & & & & 4 & 1 & 0 & 5 \\
\hline Achievement & $\begin{array}{l}\text { Personal success } \\
\text { and competence }\end{array}$ & $\begin{array}{l}\text { Define: } \\
\text { 'Attainment' (h) } \\
\text { Assess (1: } \\
\text { 'Attainment' (h) }\end{array}$ & & & & & $\begin{array}{l}\text { Define: } \\
\text { 'Learning' (h) } \\
\text { 'Work-effectively } \\
\text { together' (h) }\end{array}$ & $\begin{array}{l}\text { Define: } \\
\text { 'Learning } \\
\text { platform' } \\
\text { (c) }\end{array}$ & & & $\begin{array}{l}\text { Define: } \\
\text { 'Learning' } \\
\text { (c) }\end{array}$ & & & 16 & 2 & 2 & 20 \\
\hline $\begin{array}{l}\text { Hedonism } \\
\text { (Enjoyment) }\end{array}$ & $\begin{array}{l}\begin{array}{l}\text { Pleasure } \\
\text { sensuous and } \\
\text { gratification }\end{array}\end{array}$ & $\begin{array}{l}\text { Define: 'Positive' } \\
\text { (e) (Calming' * } \\
\text { (e) } \\
\text { Define: }\end{array}$ & & & & & & & & & & & & 12 & 1 & 1 & 14 \\
\hline Stimulation & $\begin{array}{l}\begin{array}{l}\text { Excitement, } \\
\text { novelty } \\
\text { challenge }\end{array} \text { and }\end{array}$ & $\begin{array}{l}\text { 'Innovative', (h) } \\
\text { 'Innovation' (j) } \\
\text { Assess } \\
\text { 'Innovative' (h) }\end{array}$ & & & & & $\begin{array}{l}\text { Assess 2: } \\
\text { 'Innovative' (h) }\end{array}$ & & & & & & & 5 & 1 & 1 & 7 \\
\hline Self-direction & $\begin{array}{l}\text { Independent } \\
\text { thought and } \\
\text { action }\end{array}$ & & $\begin{array}{l}\text { Define: } \\
\text { 'Choice' (e) } \\
\text { 'Freely' (e) }\end{array}$ & & & & & & & & & & & 5 & 0 & 0 & 5 \\
\hline Define & & 5 & 2 & 1 & 1 & 0 & 8 & 2 & 3 & 2 & 1 & 5 & 1 & & & & \\
\hline Assess 1 & & 2 & 0 & $\mathbf{0}$ & 0 & 0 & 0 & 0 & 0 & 0 & 0 & 0 & 0 & & & & \\
\hline Assess 2 & & 2 & 2 & 0 & 0 & 1 & 4 & 0 & 0 & 0 & 0 & 2 & 0 & & & & \\
\hline Total & & 9 & 4 & 1 & 1 & 1 & 12 & 2 & 3 & 2 & 1 & 7 & 1 & & & & \\
\hline Stakeholders & & 3 & 3 & 1 & 1 & 1 & 3 & 2 & 2 & 1 & 1 & 3 & 1 & & & & \\
\hline $\begin{array}{l}\text { Total } \\
\text { Coverage }\end{array}$ & & $40 \%$ & $20 \%$ & $10 \%$ & $10 \%$ & $10 \%$ & $30 \%$ & $20 \%$ & $10 \%$ & $20 \%$ & $10 \%$ & $20 \%$ & $10 \%$ & & & & \\
\hline
\end{tabular}

